\title{
Recombinant $T$ cell receptors specific for HLA-A*02:01-restricted neoepitopes containing KRAS codon 12 hotspot mutations
}

\author{
Craig M. Rive ${ }^{1}$, Eric Yung ${ }^{1}$, Christopher S. Hughes ${ }^{1}$, Scott D. Brown ${ }^{1}$, Govinda Sharma ${ }^{1}$, Lisa Dreolini $^{1}$, \\ Nasrin M. Mawji ${ }^{1}$, Cassia Warren ${ }^{2}$, Joanna M. Karasinska ${ }^{2}$, Jonathan M. Loree ${ }^{3}$, Donald T. Yapp ${ }^{5}$, Gregg B. \\ Morin $^{1,6}$, Daniel J. Renouf ${ }^{2,3}$, David F. Schaeffer ${ }^{2,4}$, Simon Turcotte ${ }^{7}$ and Robert A. Holt ${ }^{1,6,8, *}$ \\ ${ }^{1}$ Canada's Michael Smith Genome Sciences Centre, BC Cancer; Vancouver, BC, V5Z 1L3; Canada \\ ${ }^{2}$ Pancreas Centre BC, Vancouver, British Columbia V5Z 1L8, Canada \\ ${ }^{3}$ Department of Medical Oncology, BC Cancer, Vancouver, British Columbia V5Z 4E6, Canada. \\ ${ }^{4}$ Department of Pathology and Laboratory Medicine, University of British Columbia, Vancouver, British Columbia \\ V6T 2B5, Canada \\ ${ }^{5}$ Department of Experimental Therapeutices, BC Cancer, Vancouver, BC, V5Z 1L3; Canada \\ ${ }^{6}$ Department of Medical Genetics; University of British Columbia; Vancouver, BC, V6H 3N1; Canada \\ ${ }^{7}$ Hepatopancreatobiliary Surgery Service, Centre hospitalier de l'Université de Montréal; Montreal,Quebec, Canada \\ ${ }^{8}$ Department of Molecular Biology and Biochemistry; Simon Fraser University; Burnaby, BC, V5A 1S6; Canada \\ *Correspondence: $\underline{\text { hholt @ bcgsc.ca }}$
}

\begin{abstract}
KRAS codon 12 mutations are among the most common hotspot mutations in human cancer. Using a functional screening platform we set out to identify $\alpha \beta$ T-cell receptors (TCRs) as potential targeting reagents for KRAS ${ }^{\mathrm{G} 12 \mathrm{D}}$ and/or $\mathrm{KRAS}^{\mathrm{G} 12 \mathrm{~V}}$ neoepitopes presented by the prevalent HLA-A*02:01 allele. Here we describe isolation and characterization of three distinct $\mathrm{CD}^{+} \mathrm{T}$ cell clones from a pre-treated 76 year old patient with pancreatic ductal adenocarcinoma (PDAC). One clone was $\mathrm{KRAS}^{\mathrm{G} 12 \mathrm{~V}}$ reactive and two clones were $\mathrm{KRAS}^{\mathrm{G} 12 \mathrm{D}}$ reactive Tetramer staining showed high specificity of each $\mathrm{T}$ cell clone for its cognate HLA-A*02:01 restricted $\mathrm{KRAS}^{\mathrm{G} 12 \mathrm{~V}}$ or $\mathrm{KRAS}^{\mathrm{G} 12 \mathrm{D}}$ neoepitope (>98\% tetramer positive) without appreciable crossreactivity to wild-type KRAS ( $<2 \%$ tetramer positive). We amplified and sequenced the full-length TCR alpha and beta chains from each of the three $\mathrm{T}$ cell clones and determined that these three TCRs comprised distinct combinations of two different TCR alpha chains and two distinct TCR beta chains. We resynthesized these TCR alpha and beta chain nucleotide sequences and reconstituted the original pairs in healthy donor $\mathrm{CD}^{+} \mathrm{T}$ cells by lentiviral transduction, substituting the human $\alpha \beta$ TCR constant gene segments with murine $\alpha \beta$ TCR constant gene segments to prevent mispairing with endogenous TCR subunits. Tetramer analysis and IFN- $\gamma$ ELISpot analysis confirmed the specificity of each reconstituted TCR for its cognate HLA-A*02:01 restricted KRAS neoepitope. To test cytolytic activity TCR-transduced healthy donor $\mathrm{CD} 8^{+} \mathrm{T}$ cells were co-cultured with $\mathrm{KRAS}^{\mathrm{G} 12 \mathrm{~V}}$, KRAS $^{\mathrm{G} 12 \mathrm{D}}$ or KRAS ${ }^{\mathrm{wt}}$ peptide-pulsed K562-HLA-A*02:01 antigen presenting cells at an effector to target cell ratio of 4:1. Under these conditions we observed neoepitope-specific killing of $16.5 \%$ to $19.0 \%$ of target cell populations. To assess in vivo activity we developed a $\mathrm{KRAS}^{\mathrm{G} 12 \mathrm{~V}} / \mathrm{A} * 02: 01$ patient-derived xenograft $(\mathrm{PDX})$ mouse model. Over a 56-day period, PDX bearing mice infused with human TCR-transduced T cells had significantly reduced tumor growth and longer survival compared to mice infused with non-transduced control $\mathrm{T}$ cells. In conjunction with other therapeutic approaches, immune effector cell therapies expressing these TCRs may improve outcomes for HLA-A*02:01 patients with KRAS ${ }^{\mathrm{G} 12 \mathrm{~V}}$ and/or KRAS ${ }^{\mathrm{G} 12 \mathrm{D}}$ positive tumors.
\end{abstract}

Keywords: Neoantigens, Immune effector cells, Autologous T cell therapy, Immunotherapy, Gene therapy, TCR therapeutics

\section{Introduction}

The p21/ras proteins are a family of highly conserved intracellular GTPases that mediate key cell proliferation and differentiation pathways via the RAS/MAPK pathway. Ras proteins typically acquire oncogenic potential as the result of single amino acid substitutions in codons 12, 13, or 61. KRAS codon 12 mutations are among the most common hotspot mutations in human cancer. They are particularly frequent in pancreatic ductal adenocarcinoma
(PDAC), where they are also associated with poor prognosis (1). Over $90 \%$ of PDAC tumours are KRAS mutation positive with approximately $37 \%$ of tumours bearing a KRAS ${ }^{G 12 D}$ mutation and approximately $29 \%$ of tumours bearing a $\mathrm{KRAS}^{\mathrm{G} 12 \mathrm{~V}}$ mutation. KRAS codon 12 mutations are also frequently observed in colorectal adenocarcinomas (13\% $\mathrm{KRAS}^{\mathrm{G} 12 \mathrm{D}}$; $\left.9 \% \quad \mathrm{KRAS}^{\mathrm{G} 12 \mathrm{~V}}\right)$ and adenocarcinomas of the lung $\left(4 \% \mathrm{KRAS}^{\mathrm{G} 12 \mathrm{D}} ; 6 \%\right.$ $\mathrm{KRAS}^{\mathrm{G} 12 \mathrm{~V}}$ ) where they are likewise associated with 
worse outcome (2-7). These mutation frequencies are from the GENIE consortium's analysis of extensive clinical-grade tumour genome data (8), and recapitulate findings from earlier, large-scale tumour genome sequencing efforts (9-11) and independent studies (12-15). Codon 12 mutations in the KRAS protein cause it to become locked in an activated GTP-bound state, which constitutively activates growth signaling and increases the likelihood of oncogenic transformation of the mutated cells (16). Difficulty exploiting KRAS mutations pharmacologically has prompted exploration of this oncogene as an immunological target (17-19). It has been shown previously that KRAS codon 12 containing mutant peptides processed intracellularly and presented at the cell surface bound to MHC Class I receptors are capable of eliciting a cytolytic $\mathrm{T}$ cell response against the mutated cell $(20,21)$. In silico epitope prediction methods applied to comprehensive tumour mutation datasets support the possibility that highly recurrent KRAS hotspot mutations yield highly recurrent neoepitopes (22-25).

Recently, Wang et al. isolated restricted $\mathrm{KRAS}^{\mathrm{G} 12 \mathrm{D}}$ and KRAS ${ }^{\mathrm{G} 12 \mathrm{~V}}$ reactive T-cell receptors (TCRs) from HLA-A*11:01 ${ }^{+}$transgenic mice and observed that human peripheral blood mononuclear cells (PBMCs) transduced with these TCRs could recognize HLA-A*11:01 ${ }^{+}$tumour lines bearing the canonical KRAS mutations. Adoptive transfer of PBMC tranduced with these TCRs significantly reduced tumour growth in an HLA-A*11:01, $\mathrm{KRAS}^{\mathrm{G} 12 \mathrm{D}}$ mutated pancreatic cell line xenograft model (26). Subsequently, Tran et al. isolated and expanded tumour infiltrating $\mathrm{T}$ cells reactive against an HLA-C*08:02-restricted KRAS ${ }^{\text {G12D }}$ neoepitope from a patient with metastatic colon cancer (27). Infusion of this autologous cell product as part of a clinical trial led to regression of the patient's metastatic lung lesions, but loss of expression of the HLA-C*08:02 allele in one of the lesions allowed subsequent progression of disease (27). These findings are encouraging and support the notion that anti-tumour T-cell responses targeting HLA class I neoepitopes originating from mutant KRAS proteins are potentially therapeutically relevant.
We set out to identify TCRs that could be used to produce TCR-transduced $\mathrm{T}$ cell products for treating tumours possessing $\mathrm{KRAS}^{\mathrm{G} 12 \mathrm{D}}$ and/or $\mathrm{KRAS}^{\mathrm{G} 12 \mathrm{~V}}$ neoepitopes presented by the highly prevalent HLA-A*02:01 allele. HLA frequency varies by population, with HLA-A*02:01 frequencies as high as $54.5 \%$ in North American populations, $34.4 \%$ in European populations, $40.5 \%$ in Asian populations, and $18.4 \%$ in African populations, according to study data compiled by the Allele Frequency Net Database (28). Here, we describe screening PBMC from a 76 year old HLA-A*02:01 patient diagnosed with a stage 2 primary PDAC tumour, arising at the pancreatic tail, with regional lymph node involvement but no distant metastasis. PBMC used for TCR discovery were obtained post-operatively, prior to chemotherapy and radiation therapy that were delivered in the adjuvant setting. From this subject we isolated three HLA-A*02:01 restricted T cell clones; two specific for the $\mathrm{KRAS}^{\mathrm{G} 12 \mathrm{D}}$ amino acid 5-14 epitope (KLVVVGADGV) and one specific for the $\mathrm{KRAS}^{\mathrm{G} 12 \mathrm{~V}}$ amino acid 5-14 epitope (KLVVVGAVGV). We amplified, sequenced, and resynthesized the alpha and beta TCR chains from these $\mathrm{T}$ cell clones and reconstituted them in HLA-A*02:01 healthy donor $\mathrm{CD}^{+} \mathrm{T}$ cells. These TCR-modified healthy donor $\mathrm{T}$ cells recapitulated the epitope specific binding and cytolytic activity of the original clones and showed efficacy in a PDAC patientderived xenograft (PDX) tumour model.

\section{Results}

We first confirmed that the KRAS 5-14 peptide could be naturally processed and presented. We used PANC-1 cells which are heterozygous for both the KRAS ${ }^{\mathrm{G} 12 \mathrm{D}}$ mutation and the HLA-A*02:01 allele (29). The mutant peptide was detectable by surface elution and targeted Multiple Reaction Monitoring (MRM) mass spectrometry (Figure S1), although at a lower level than the KRAS ${ }^{\mathrm{wt}}$ peptide.

Next, to isolate neoantigen-specific $\mathrm{CD}^{+}$ T cells we deployed a "miniline" functional screening platform that we previously established to evaluate the $\mathrm{T}$ cell response to High Grade Serous Ovarian Cancer $(30,31)$. Briefly, polyclonal $\mathrm{CD}^{+} \mathrm{T}$ cells were magnetically sorted from PBMC, distributed in 96 
well plates at a density of several thousand T cells per well, expanded non-specifically, rested, and then screened by interferon-gamma (IFN- $\gamma$ ) ELISpot for reactivity against peptide-pulsed K562-HLA*02:01 artificial Antigen Presenting Cells (aAPC). T cells from positive pools that showed up-regulation of the CD137 activation marker when co-incubated with peptide-pulsed aAPC were sorted into individual wells of a 96 well plate and clonally expanded. Using this approach we isolated one HLA-A*02:01restricted $\mathrm{KRAS}^{\mathrm{G} 12 \mathrm{~V}}$ specific $\mathrm{T}$ cell clone and two HLA-A*02:01-restricted KRAS ${ }^{\text {G12D }}$ T cell clones. We were somewhat surprised to recover $\mathrm{T}$ cell clones reactive to both $\mathrm{KRAS}^{\mathrm{G} 12 \mathrm{~V}}$ and $\mathrm{KRAS}^{\mathrm{G} 12 \mathrm{D}}$ neoepitopes from a single subject. These mutations have previously been reported to co-occur in some patients (32), but we did not have access to tumour material to determine the mutational status of this particular subject. However, HLA class I typing of the three $\mathrm{T}$ cell clones verified they are matched (HLA-A*02:01, -A*01:01, -B*07:02, -B*44:02, $C^{*} 07: 02$, and $\left.-C^{*} 05: 01\right)$ providing assurance these $\mathrm{T}$ cells do in fact originate from the same patient.Tetramer staining showed high specificity of each $\mathrm{T}$ cell clone for its cognate HLA-A*02:01restricted KRAS neoepitope (Figure 1). Specifically, $99.0+/-0.1 \%$ (mean +/- SD) of the HLA-A*02:01restricted, $\mathrm{KRAS}^{\mathrm{G} 12 \mathrm{~V}}$-specific monoclonal $\mathrm{T}$ cells stained positive for the $\mathrm{KRAS}^{\mathrm{G} 12 \mathrm{~V}}$ - $\mathrm{A}^{* 02: 01}$ tetramer. The two HLA-A*02:01-restricted, KRAS $^{\mathrm{G} 12 \mathrm{D}-}$ specific monoclonal $\mathrm{T}$ cells stained 99.3 $+/-0.1 \%$ and $98.8+/-0.9 \%$ positive for the KRAS $^{\text {G12D }}$ - A*02:01 tetramer, respectively. Each T cell clone stained $<2 \%$ positive for KRAS wild-type HLA-A*02:01 tetramer. Of note, we initially attempted to isolate KRAS neoeptiope reactive $\mathrm{CD}^{+}$ $\mathrm{T}$ cells directly from patient $\mathrm{PBMC}$ by tetramer sorting, but these attempts did not lead to successful expansion of any $\mathrm{T}$ cell clones, necessitating our adoption of the more comprehensive miniline-based search strategy described here.

Next, we amplified and sequenced (33) the full-length TCR alpha and beta chains from each of the three $\mathrm{T}$ cell clones which revealed two distinct alpha chains and two distinct beta chains shared among the three clones (Table 1). The nucleotide sequences encoding the cognate TCR alpha and beta chain pair for each $\mathrm{T}$ cell clone were synthesized and inserted, in the configuration Alpha-T2A-Beta-P2AmStrawberry, into a lentiviral transfer plasmid (34), under control of the human EF1 $\alpha$ promoter. The synthetic TCRs corresponding to each of T cell clones 1, 2 and 3 are referred to hereafter as KTCR1, $K T C R 2$, and KTCR3, respectively. In each of these synthetic TCRs the human constant gene segment of each chain was replaced with the orthologous murine constant gene segment to facilitate correct alpha-beta chain pairing (36). Replication-incompetent lentivirus was generated for each KTCR construct and used to transduce $\mathrm{CD}^{+} \mathrm{T}$ cells obtained from HLA-A*02:01 ${ }^{+}$ normal healthy donors, followed by sorting and expansion of successfully transduced $\mathrm{T}$ cells from each population.

Tetramer analysis of TCR-transduced T cells mirrored the results observed from tetramer analysis of the original $\mathrm{T}$ cell clones. Specifically, $83.7+/-$ $0.5 \%$ (mean +/- SD) of KTCR1-transduced $\mathrm{CD}^{+}$ $\mathrm{T}$ cells stained positive for the KRAS ${ }^{\mathrm{G} 12 \mathrm{~V}}-\mathrm{A}^{*} 02: 01$ tetramer, $89.3+/-0.5 \%$ of KTCR2-transduced $\mathrm{CD}^{+}$ $\mathrm{T}$ cells stained positive for the KRAS ${ }^{\mathrm{G} 12 \mathrm{D}}-\mathrm{A}^{*}$ 02:01 tetramer and $88.7+/-0.5 \%$ of KTCR3-transduced $\mathrm{CD}^{+} \mathrm{T}$ cells likewise stained positive for the $\mathrm{KRAS}^{\mathrm{G} 12 \mathrm{D}}$ - $\mathrm{A}^{*} 02: 01$ tetramer. Each population of KTCR transduced $\mathrm{T}$ cells stained $<5 \%$ positive for the KRAS wild-type HLA-A*02:01 tetramer (Figure 2).

Further verification of specificity was obtained by IFN- $\gamma$ ELISpot analysis (Figure 3A) using HLA-A*02:01 transduced K562 aAPCs pulsed with the $\mathrm{KRAS}^{\mathrm{G} 12 \mathrm{D} / \mathrm{V}}$ peptides. KTCR1-transduced $\mathrm{CD}^{+} \mathrm{T}$ cells produced $734+/-157$ IFN $\gamma$ spot forming units (SFU) per million cells when cocultured with KRAS $^{\mathrm{G} 12 \mathrm{~V}-}$ peptide-pulsed K562$A^{*} 02: 01$ target cells $(50,000$ cells each at a ratio of $1: 1)$, compared to $\mathrm{KRAS}^{\mathrm{G} 12 \mathrm{D}-}$ and $\mathrm{KRAS}^{\mathrm{wt}}$ pulsed target cells, which produced $31+/-47$ and $26+/-43$ SFU/million cells, respectively $(\mathrm{p}<0.001)$. The KTCR2-transduced CD8 ${ }^{+} \mathrm{T}$ cells produced $360+/-77$ IFN $\gamma$ SFU per million cells when co-cultured with $\mathrm{KRAS}^{\mathrm{G} 12 \mathrm{D}-}$ peptide-pulsed target cells, compared to $\mathrm{KRAS}^{\mathrm{G} 12 \mathrm{~V}-}$ and $\mathrm{KRAS}^{\mathrm{wt}}$ pulsed target cells which produced $26+/-40$ and $26+/-52 \mathrm{SFU} /$ million cells, 
respectively ( $\mathrm{p}<0.001)$. KTCR3-transduced $\mathrm{CD} 8^{+} \mathrm{T}$ cells produced $647+/-162$ IFN $\gamma$ SFU/million cells when co-cultured with $\mathrm{KRAS}^{\mathrm{G} 12 \mathrm{D}}$-peptide-pulsed target cells compared to $\mathrm{KRAS}^{\mathrm{G12} \mathrm{V}-}$ and $\mathrm{KRAS}^{\mathrm{wt}}$ pulsed target cells which produced $87+/-62$ and 29 $+/-28 \mathrm{SFU} / \mathrm{million}$ cells, respectively $(\mathrm{p}<0.001$ and $\mathrm{p}<0.002$, respectively) (Figure 3A).

The function of KTCR1-, KTCR2-, or KTCR3-transduced $\mathrm{CD}^{+} \mathrm{T}$ cells was evaluated using cytotoxic assays. Transduced $\mathrm{T}$ cells were co-cultured for 5 hours with peptide-pulsed K562-HLA-A*02:01 target cells at an effector to target cell ratio of $4: 1$. Killing of aAPC was measured using vital staining and flow cytometric analysis. The KTCR1-transduced $\mathrm{CD}^{+} \mathrm{T}$ cells killed $16.5+/-2.41 \%$ (mean +/- SD) of the $\mathrm{KRAS}^{\mathrm{G12D}}$ peptide-pulsed target cells compared to $4.0+/-2.5 \%$ of $\mathrm{KRAS}^{\mathrm{G} 1 \mathrm{~V}-}$ and $2.9+/-2.7 \%$ of KRAS $^{\text {WT- }}$ pulsed target cells. The KTCR2-transduced $\mathrm{CD}^{+} \mathrm{T}$ cells killed $19.1+/-3.0 \%$ of $\mathrm{KRAS}^{\mathrm{G} 12 \mathrm{D}-}$ pulsed target cells compared to $4.0+/-2.6 \%$ of $\mathrm{KRAS}^{\mathrm{G} 12 \mathrm{~V}_{-}}$and $4.8+/-2.9 \%$ of $\mathrm{KRAS}^{\mathrm{WT}}$ pulsed target cells $(\mathrm{p}<0.001)$. KTCR3-transduced $\mathrm{CD}^{+} \mathrm{T}$ cells killed $16.6+/-2.4 \%$ of $\mathrm{KRAS}^{\mathrm{G} 12 \mathrm{D}-}$ pulsed target cells compared to $4.0+/-2.6 \%$ of $\mathrm{KRAS}^{\mathrm{G} 12 \mathrm{~V}-}$ and 4.8 $+/-2.9 \%$ of KRAS $^{\text {WT- }}$ pulsed target cells ( $\mathrm{p}<0.001$ ) (Figure 3B).

KTCR1 was assessed in vivo using a PDX mouse model. Initially, we screened a number of PDX samples in order to find one which possessed both the KRAS ${ }^{\mathrm{G} 12 \mathrm{~V}}$ mutation and the HLA-A*02:01 allele. Once a suitable PDX sample was identified, tumours were expanded by passaging them in CB17SC-M mice. Expanded PDX tumours were then surgically implanted into experimental CB17SC-M mice and once tumours were established and had reached an average size of $100 \mathrm{~mm}^{3}$ the mice were infused with either KTCR1-transduced $\mathrm{CD}^{+} \mathrm{T}$ cells or with an equivalent dose of control $\mathrm{CD}^{+} \mathrm{T}$ cells expanded from the same donor but lacking KTCR1 expression. The reasoning behind treating mice with established tumours rather than early stage tumours was to better emulate a clinical setting. Infusion of the KTCR1-transduced $\mathrm{CD}^{+} \mathrm{T}$ cells on day 25 led to reduced tumour growth almost immediately post infusion, relative to control mice, with a statistically significant reduction at day $44(\mathrm{p} \leq 0.02)$ and beyond
( $\mathrm{p} \leq 0.002$ at Day 56) (Figure 4A). We humanely euthanized mice once the tumours reached a size of $1000 \mathrm{~mm}^{3}$ and used this as a proxy for survival. The mice treated with the KTCR1-transduced $\mathrm{CD}^{+} \mathrm{T}$ cells showed longer survival compared to mice treated with $\mathrm{CD}^{+} \mathrm{T}$ cells that did not express KTCR1 ( $\mathrm{p} \leq 0.05)$ (Figure 4B).

\section{Discussion}

We have isolated, from a newly diagnosed 76 year old PDAC patient, three distinct $\alpha \beta T C R s$ specific for HLA-A*02:01-binding $\mathrm{KRAS}^{\mathrm{G} 12 \mathrm{~V}}$ and $\mathrm{KRAS}^{\mathrm{G} 12 \mathrm{D}}$ neoepitopes.

Interestingly, we observed that the HLAA*02:01-restricted KRAS ${ }^{\mathrm{G} 12 \mathrm{~V}}$ specific KTCR1 and HLA-A*02:01-restricted KRAS ${ }^{\text {G12D }}$ KTCR2 shared the same beta chain, suggesting that mutation specific binding was conferred by the alpha chain. However, we also observed that HLA-A*02:01-restricted $\mathrm{KRAS}^{\mathrm{G} 12 \mathrm{~V}}$ specific KTCR1 and HLA-A*02:01restricted KRAS ${ }^{\mathrm{G} 12 \mathrm{D}}$ specific KTCR3 shared the same alpha chain, which would suggest the opposite, that the beta chain confers mutation specificity (Table 1). The simplest explanation for these observations would be that these were not pure clones but rather mixed populations. However, upon careful inspection, the sequence data indicated no polyclonality and HLA class I typing of the individual $\mathrm{T}$ cell clones confirmed that they did in fact come from the same patient. The existance of natural, mixed-chain TCRs with distinct specificities suggests that engineering therapeutic TCRs with novel subunit combinations could be beneficial.

Historically, there have been many efforts to exploit recurrent KRAS somatic point mutations as pharmacological targets, but mutant KRAS remains largely "undruggable". Much recent attention has been given to the development of $\mathrm{KRAS}^{\mathrm{G} 12 \mathrm{C}}$ inhibitors, a number of which are currently in various stages of development and testing. One of these, AMG150 (37-41), was shown to produce durable regression of tumours in mice, even if $\mathrm{KRAS}^{\mathrm{G} 12 \mathrm{C}}$ is expressed heterogeneously. It was also shown in a murine model that inhibiting the actions of the activated $\mathrm{KRAS}^{\mathrm{G} 12 \mathrm{C}}$ mutant, in the presence of the PD-1 inhibitor pembrolizumab, led to the clearance of 
KRAS $^{\mathrm{G} 12 \mathrm{C}}$ tumours and subsequent rejection of $\mathrm{KRAS}^{\mathrm{G} 12 \mathrm{D}}$ tumour grafts, substantiating these codon 12 mutations as neoantigenic.

There is potential to exploit $\mathrm{KRAS}^{\mathrm{G} 12 \mathrm{~V}-}$ and KRAS $^{\mathrm{G} 12 \mathrm{D}}$-specific recombinant TCRs in engineered Immune Effector Cell (IEC) therapies. Similar to the Chimeric Antigen Receptor (CAR) T-cell therapeutic approach, a patient's autologous T-cells could be genetically modified to express the relevant KTCR, followed by ex vivo cell expansion and re-infusion. This method can generate a large number of antigen specific $T$ cells with the potential to eliminate tumour cells and impart immune memory against neoantigens originating from this potent oncogene. In this manner, an IEC therapy deploying these TCRs, alone or in conjunction with standard therapies, could improve outcomes for cancer patients that carry the common HLA-A*02:01 allele and the common $\mathrm{KRAS}^{\mathrm{G} 12 \mathrm{~V}}$ or $\mathrm{KRAS}^{\mathrm{G} 12 \mathrm{~V}}$ mutations.

\section{Materials and Methods.}

Sample acquisition and storage. Patient samples were obtained from the BC Gastrointestinal and Pancreatic (GIP) Biobank, a repository of tissue and blood samples donated by patients with pancreatic disease. Control $\mathrm{T}$ cells were isolated from from leukapheresis products from healthy donors (STEMCELL Technologies, Vancouver, BC, Canada). This study was approved by the Research Ethics Board of the BC Cancer Agency/University of British Columbia (certificates H16-00291-A021, H19-01738). PBMCs from the patient samples and healthy donor were isolated by Ficoll gradient purification as per manufactures protocol (Ficoll, GE17-1440, GE Healthcare). The isolated PBMC were stored by resuspending cells in cryopreservation media in aliquots of $5-10 \times 10^{6}$ cells per $\mathrm{ml}$ and storaed on liquid nitrogen.

Patient details. The patient was a 76 year old woman who was diagnosed after initial imaging identification and curative intent resection. The pathological diagnosis was that the patient had an invasive, well to moderately differentiated pancreatic adenocarcinoma, arising from an intraductal papillary mucinous neoplasm (IPMN), that exhibited regional lymph node metastases. The PBMC sample from which the TCRs were identified was acquired at the time of diagnosis and prior to any treatment. Post surgery, the patient received 3 cycles of adjuvant gemcitabine, then concurrent chemoradiotherapy with capecitabine and radiation therapy (50 Gy in 25 fraction) due to a positive margin. The patient then completed another 5 cycles of gemcitabine. Approximately 23 months after the original diagnosis, the patient experienced disease recurrence and passed away 14 months after the recurrence diagnosis.

Cell culture media. All cell cultures were maintained in either a RPMI-1640 (Invitrogen, 11875-119) supplemented media or a DMEM (Invitrogen, 11995073) supplemented media. RPMI-1640 supplemented media consisted of $2 \mathrm{mM}$ GlutaMAX (Invitrogen, 35050-061), $1 \mathrm{mM}$ MEM non-essential amino acid (Invitrogen, 11140-050), $1 \mathrm{mM}$ sodium pyruvate (Invitrogen, 11360-070), $10 \mathrm{mM}$ HEPES (Invitrogen, 15630-808), $100 \mathrm{U} / \mathrm{mL}$ penicillin/streptomycin (Invitrogen, 15140-122), MycoZap prophylactic (Lonza, VZA-2031), and 10\% heat-inactivated fetal bovine serum (HI-FBS, Invitrogen, 12484028). DMEM supplemented media consisted of $2 \mathrm{mM}$ GlutaMAX , $1 \mathrm{mM}$ MEM non-essential amino acid, $100 \mathrm{U} / \mathrm{mL}$ penicillin- streptomycin, MycoZap prophylactic, and $10 \%$ HI-FBS. We used an in house MACS separation buffer comprised of D-PBS (Gibco, 59331C) with 2mM EDTA (ThermoFisher, 15575020) and 2\% HI-FBS. FACS media consisted of D-PBS with $2 \%$ HI-FBS. Cryopreservation media consisted of HI-FBS with $10 \%$ DMSO, (Fisher Scientific, BP231-100). All media and supplements were filtered through a $0.22 \mu \mathrm{M}$ filter (VWR, 28199730) and stored at $4^{\circ} \mathrm{C}$. All cultures were maintained at $37^{\circ} \mathrm{C}$ and $5 \% \mathrm{CO}_{2}$ atmosphere.

Isolation of $T$ cell clones. Screening patient $T$ cells entailed a modified "mini-line" culture method, previously described by Martin et al. and Wick et al. $(30,31) . \mathrm{CD}^{+} \mathrm{T}$ cells were isolated from the patient PBMC sample using the Miltenyi MACS human $\mathrm{CD}^{+}$isolation kit, following the manufacturer's protocol (Miltenyi, 130-096-495) and using an in house MACS separation buffer. The isolated $\mathrm{CD}^{+} \mathrm{T}$ 
Rive et al., 15 Jun 2020 - preprint copy - BioRxiv

cells were then centrifuged at $400 \mathrm{xg}$ for $10 \mathrm{~min}$ (Eppendorf Centrifuge 5810R, rotor A-4-62) at room temperature, the supernatant was removed, and the cell pellet resuspended in sRPMI-1640 media. Cell numbers were obtained using the Countess automated cell counter (Thermofisher). The cells were then centrifuged and the cell pellet resuspended in RPMI1640 supplemented media with $300 \mathrm{U} / \mathrm{mL}$ rhIL-2 (Peprotech, 200-02 and StemCell, 78036.3), 100 ng/mL of anti-CD3 (eBiosciences, 16-0037-85), 100 $\mathrm{ng} / \mathrm{mL}$ anti-CD28 (BioLegend, 302943) soluble antibodies at a concentration of 20,000 cells/ $\mathrm{ml}$. $100 \mu \mathrm{l}(2000$ cells) were then plated into individual wells within a 96-well U-shaped plate (Thermo Fisher Scientific, 08-772-54) with an excess of allogeneic irradiated PBMCs feeders $\left(2 \times 10^{5}\right.$ cells irradiated with $50 \mathrm{~Gy}$, per $2000 \mathrm{~T}$ cells). Cells were cultured for 14 days and then were split into replicate plates on days $5,7,9,11$, and 13 of the culture. Fresh RPMI-1640 supplemented media with rhIL-2 was added to the split cultures, giving a final volume of $200 \mu \mathrm{l}$ and a final rhIL-2 concentration of $300 \mathrm{IU} / \mathrm{ml}$. On day 14, cells were washed with RPMI-1640 supplemented media and then rested for 2-4 days in RPMI-1640 supplemented media with $10 \mathrm{IU} / \mathrm{ml}$ rhIL-2 before each individual well was screened for $\mathrm{KRAS}^{\mathrm{G} 12 \mathrm{D} / \mathrm{V}}$ peptide reactivity. Reactive $\mathrm{T}$ cells were single-cell sorted by Fluorescence Activated Cell Sorting (FACS) (Figure S2) based on detection of 4-1BB (CD137) expression, after being re-stimulated for 24 hours with HLA-A*02:01 positive aAPCs pulsed with up to $10 \mu \mathrm{g} / \mathrm{mL}$ of the relevant $\mathrm{KRAS}^{\mathrm{G} 12 \mathrm{D} / \mathrm{V}}$ peptides. After the co-culture, cells were stained with the surface staining antibodies, CD8-FITC and 4-1BBCD137 APC (1/100, BioLegend). Cells were incubated at $37^{\circ} \mathrm{C}$ for $10 \mathrm{~min}$, then washed by adding $2 \mathrm{~mL}$ of FACS media to each tube and centrifuging for 10 minutes at $400 \mathrm{xg}$ at room temperature. The supernatant was discarded before resuspension in $500 \mu \mathrm{l}$ of FACS media with PI (1/1000, Invitrogen, P1304MP). Acquisition was performed on the BD LSRFortessa cell analyser, and analyzed using FlowJo and GraphPad Prism and sorted using BD FACS Aria. The monoclonal T cells were sorted into single wells of a 96-well U-shaped plate and expanded in RPMI-1640 supplemented media with
rhIL-2 (300U/mL) and an excess of allogeneic irradiated PBMCs feeders $\left(2 \times 10^{4}\right.$ cells irradiated with 50 Gy, per single $\mathrm{T}$ cells). The expanded candidate $\mathrm{T}$ cell clones were either resuspended in cryopreservation media and stored in liquid nitrogen or resuspended in RNAlater (invitrogen, AM7020) and stored as per the manufactures recommendations.

HLA-class I typing. Candidate $\mathrm{T}$ cell clones were subjected to class I HLA sequencing and typing to verify identity. DNA was extracted from the $\mathrm{T}$ cells using the DNeasy Blood and Tissue kit (Qiagen, 69504) following the manufacturer's protocol. To amplify the HLA-A, HLA-B, and HLA-C genes, PCR was performed using primers for HLA-A (forward 5GAAACSGCCTCTGYGGGGAGAAGCAA and Reverse 5-TGTTGGTCCCAATTGTCTCCCCTC), HLA-B (forward 5- GGGAGGAGCGAGGGGACCS CAG and Reverse 5-GGAGGCCATCCCCGGCG ACCTAT), and HLA-C (forward 5- AGCGAGG KGCCCGCCCGGCGA and Reverse 5- GGAG ATGGGGAAGGCTCCCCACT). The PCR assays were run using LA Taq polymerase (Takara Bio, TAKRR002) with the following thermocycling conditions: one cycle at $94^{\circ} \mathrm{C}$ for $4 \mathrm{~min} ; 28$ cycles at $98^{\circ} \mathrm{C}$ for $10 \mathrm{sec}$ and $72^{\circ} \mathrm{C}$ for 4 minutes before cooling down and being held at $10^{\circ} \mathrm{C}$. DNA from each sample was purified using a $1 \%$ agarose SYBR Safe e $\square$ Gel (Invitrogen, G442001) and a unique band between 850-1000bp size was excised and extracted using QIAGEN Multiple gel extraction kit (QIAGEN, 28704) before being resuspended in RNase/DNase $\square$ free water (Invitrogen, AM9916). The HLA-A, HLA-B, and HLA-C amplicons from the three $\mathrm{T}$ cell clones plus a control PBMC source were "A-tailed" by adding adenosine to the 3 ' end of the amplicons. The amplicons where then ligated into the pCR4-topo plasmid between the M13F and M13R sequences and transformed into DH5 $\alpha$ competent cells following the manufacturer's protocols (Invitrogen, 18265-017). Up to 8 colonies were selected for HLA-A, HLA-B, and HLA-C sequencing for each $\mathrm{T}$ cell clone and the control sample and DNA was isolated using a QIAprep Spin Miniprep Kit (QIAGEN, 27104). Sanger sequencing was performed using the M13F and M13R primers (Genewiz). Sequences were then matched and blasted using 
IMGT and NCBI-IgBLAST databases to identify the HLA-typing of each T cell clone (42-44).

Mass spectrometry. For MRM assay design, the HLA-A*02:01-restricted KRAS ${ }^{\text {wt }}$ (KLVVVGAGGV) and KRAS $^{\text {G12D }}$ (KLVVVGADGV) aa5-14 peptides were synthesized (Peptide 2.0) and analyzed on an Orbitrap Fusion (Thermo Scientific) mass spectrometer (MS) using a data-dependent method with MS/MS scanning in the ion trap detector. Peptides were injected and chromatographically separated using an Easy nLC 1000 system (Thermo Scientific) with a trapping-analytical column packed in-house in $75 \mu \mathrm{m}$ inner-diameter (ID) fused silica capillaries using $3 \mu \mathrm{m}$ Reprosil-Pur $\mathrm{C} 18$ beads to lengths of 3 and $25 \mathrm{~cm}$, respectively. The analytical column was heated to $45^{\circ} \mathrm{C}$ using nanoSLEEVE ovens (Analytical Sales and Services). Survey scans (MS1) were acquired with a resolution of 120,000 , a $350-1200 \mathrm{~m} / \mathrm{z}$ mass range, $32 \mathrm{~ms}$ maximum fill time, and a 200,000 automatic gain control (AGC) target. MS2 acquisition used a $1.6 \mathrm{~m} / \mathrm{z}$ isolation window, a fixed first mass of $110 \mathrm{~m} / \mathrm{z}$, a higher-energy collisional dissociation energy of 30, rapid scan mode, a $60 \mathrm{~ms}$ max fill time, and a 10,000 AGC target. Data was acquired in 60-minute runs using a 3-second maximum cycle for the above scan modes. Acquired MS2 scans were identified using Proteome Discoverer (version 1.4) by searching against the human proteome database (Uniprot, version 2014_10) (45) with the settings: precursor mass error 20ppm, fragment mass error 0.5 Daltons, carbamidomethylation as a fixed modification, and oxidation of methionine as a variable modification. Results files were imported into Skyline software and a total of 5 precursor-product ion MRM transitions were selected for specific detection of each of the wild-type and mutant peptides based on ranked intensities of the product ions.

Prior to analysis, MHC molecules were disassociated from the surface of $2 \times 10^{8}$ PANC- 1 cells by weak acid elution $(0.131 \mathrm{M}$ citric acid, $0.066 \mathrm{M}$ $\mathrm{Na} 2 \mathrm{HP} 04, \mathrm{pH} 3.0$ ). Cells were centrifuged at 400xg for 5 mins, (Eppendorf Centrifuge 5810R, rotor A-462) at room temperature. The supernatant was collected and passed over Amicon ultrafiltration device (Millipore Sigma, UFC9010, 10kDa cutoff) at $3200 x$ g for $15 \mathrm{~min}$. The resulting pool of epitopes were chemically labeled using reductive demethylation following previously established protocols (47). Synthetic peptides were processed using the same protocol, substituting deuterated formaldehyde to generate a 'medium' sample label. Labeling reactions were quenched by adding $1 \mathrm{M}$ glycine and incubating for 15-minutes at room temperature. Labeled samples were acidified using triflouroacetic acid (TFA) and cleaned-up using StageTip (3-disc plug of C18 Empore material, 3M). StageTip's were conditioned by rinsing them with (2x) $0.1 \%$ TFA in acetonitrile and (2x) $0.1 \%$ TFA in water. Final elution was performed with two steps of $0.1 \%$ TFA in $60 \%$ acetonitrile. All steps were performed with $100 \mathrm{uL}$ volumes and at a flow rate of 1 drop-per-second using a vacuum manifold unit (Waters). Labeled and desalted peptides were concentrated in a SpeedVac and dried samples reconstituted in 1\% TFA prior to MS analysis. Light labeled MHC eluted samples were spiked with medium synthetic peptides based on optimised concentrations, determined throughout the MS analysis.

Expressed epitopes presented by PANC-1 cells (ATCC® CRL-1469 ${ }^{\mathrm{TM}}$ ) were analyzed on a QTRAP $6500 \mathrm{MS}$ system coupled to an Eksigent nanoLC 415 system (AB Sciex) controlled by Analyst software (version 1.6.2). MS data acquisition was performed in non-scheduled MRM mode using a 'High' CAD gas setting, transition-specific collision energies, and a dwell time of $45 \mathrm{~ms}$ per transition. A total of 5 precursor-product ion MRM transitions were used for specific detection of each of the wildtype and mutant peptides (Table S1). All MRM MS analyses were carried out using 30-minute runs at a chromatography flow rate of $0.45 \mu \mathrm{L}$ per minute. MHC elutions were performed in triplicate and samples analyzed individually by MRM-MS. Resultant data were processed in Skyline software (46) to yield area values for each peptide that were used for calculations of peptide amounts based on established concentrations of the spiked synthetic peptide. 
Interferon-gamma ELISpot assays. The panel of polyclonal $\mathrm{T}$ cell pools was then screened for reactivity to $\mathrm{KRAS}^{\mathrm{G} 12 \mathrm{D}}$, $\mathrm{KRAS}^{\mathrm{G} 12 \mathrm{~V}}$ and $\mathrm{KRAS}^{\mathrm{w} / \mathrm{t}}$ peptides using IFN- $\gamma$ ELISpot assays following the manufacturer's protocol (MabTech). Briefly, ELISpot plates were coated with IFN- $\gamma$ capture antibody $(2$ $\mu \mathrm{g} / \mathrm{ml}$ per well, Mabtech mAb 1-D1K, 3420-7), in DPBS and then blocked with RPMI-1640 supplemented media. At an effector to target ratio of $1: 1,1 \times 10^{5}$ effector $\mathrm{CD}^{+} \mathrm{T}$ cells were incubated with $1 \times 10^{5}$ aAPCs transduced to express HLA-A*02:01, pulsed with the appropriate $\mathrm{KRAS}^{\mathrm{G} 12 \mathrm{~V} / \mathrm{D}}$ peptide $(0.1-100$ $\mu \mathrm{g} / \mathrm{mL})$. Controls included $1 \times 10^{5}$ effector $\mathrm{CD}^{+} \mathrm{T}$ cells co-cultured with anti-human CD3 monoclonal antibody (0.5 $\mu \mathrm{g} / \mathrm{mL}$, Mabtech, 3605-1-1000), or with media alone. ELISpot plates were then incubated at $37^{\circ} \mathrm{C}$ with $5 \% \mathrm{CO}_{2}$ for 18 to 22 hours, then wells were washed 5 times with sterile D-PBS and incubated with anti-IFN $\gamma$ biotinylated antibody $(1 \mu \mathrm{g} / \mathrm{mL}$ per well, Mabtech, mAb 7-B6-1, 3420-9H) for 2 hours.

The ELISpot plates were washed as described above, and incubated for 1 hour with streptavidinHRP (diluted 1:100 with D-PBS, Mabtech, 3310-91000), and then washed again. Plates were substrated for 8-12 minutes using $0.5 \mu \mathrm{M}$ filtered 3'3'5'5'Tetramethylbenzidine (TMB substrate) (Mabtech, 3652-F10) and the plates were evaluated with an AID automated microplate ELISpot reader and associated software (AID ELISpot Version 7.0).
Flow cytometry. HLA-A*02:01 - $\mathrm{KRAS}^{\mathrm{G} 12 \mathrm{~V} / \mathrm{D} / \mathrm{wt}}$ tetramer staining assays involved staining both monoclonal $\mathrm{T}$ cells and KTCR expressing cells (Figure 2). Tetramers were manufactured by the NIH Tetramer core facility and labelled with the PE fluorochrome. Cells were stained with the tetramer plus CD3-eFluor $450 \quad(1 / 100, \quad 48-0032-82$ eBioscience) and CD8-FITC (1/100, 300905 BioLegend) at $4^{\circ} \mathrm{C}$ for $30 \mathrm{~min}$. Samples were then washed by adding $2 \mathrm{~mL}$ of FACS media to each tube and centrifuging for 10 minutes at $400 \mathrm{xg}$ at $4{ }^{\circ} \mathrm{C}$. The supernatant was discarded before resuspending cells in $500 \mu \mathrm{l}$ of cold FACS media. Acquisition was performed on the BD LSRFortessa cell analyser, and analyzed using FlowJo and GraphPad Prism (Figure S3).

For cytotoxic assays the target cells, K562HLA-A*02:01 were pulsed with the appropriate KRAS associated peptide $(10 \mu \mathrm{g} / \mathrm{mL})$, stained with cell proliferation dye eFluor 450 (eBioscience, 650863-14) and then co-cultured with the effector cells (KTCR1 expressing T cells) for 5 hours. Cells were then stained with the fixable viability stain (FVS) 780 (1/100, 565388, BD Bioscience) and CD8-FITC (1/100, 300905 BioLegend) at $4^{\circ} \mathrm{C}$ for $30 \mathrm{~min}$. Samples were then washed with $2 \mathrm{~mL}$ of FACS media and centrifuging for 10 minutes at $400 \mathrm{xg}$ at $4{ }^{\circ} \mathrm{C}$. The supernatant was discarded and cells resuspended in $500 \mu \mathrm{l}$ of cold FACS media. Acquisition was performed on the BD LSRFortessa cell analyser, and analyzed using FlowJo and GraphPad Prism (Figure 3b and Figure S4).

TCR amplification and sequencing. Candidate T cell clones were subjected to alpha-beta TCR amplification and sequencing. We used an adapted version of the template-switch anchored RT-PCR method described previously (48-49) where mRNA was extracted from the candidate $\mathrm{T}$ cell clones stored in RNAlater (Invitrogen, AM7020) using the RNeasy mini kit (QIAGEN, 74104) following the manufacturer's protocol. cDNA was generated using a template $\square$ switch anchored reverse $\square$ transcription polymerase chain reaction (RT $\square$ PCR) based on the SMARTer pico cDNA PCR Synthesis Kit (Clontech, Mountain View, CA, USA). The final cDNA product 
was then subjected to a clean $\square$ up step using PCR Clean DX Beads (Aline Biosciences, C-1003). To amplify the TCR $\alpha$ and TCR $\beta$ chain, PCR was performed using a pair of primers, that bind to the template switching region (5' $\square$ CTAATACGACTCACTATAGGGCAAGCAG TGGTATCAACGCAGAGT and 5'CTAATACGACTCACTATAGGGC), and the constant region of either the $\mathrm{TCR} \alpha$ (5'-AGGCAGACAGACTTGTCACTGGATT) or TCR $\beta \quad(5, \square$ TCTCTGCTTCTGATGGCTCAAAC) sequence. The PCR assays using NEB enzyme Q5® Hot Start High-Fidelity (NEB, M0491) with the following thermocycling conditions: one cycle at $98^{\circ} \mathrm{C}$ for $30 \mathrm{sec} ; 30$ cycles at $98^{\circ} \mathrm{C}$ for $10 \mathrm{sec}, 55^{\circ} \mathrm{C}$ for $10 \mathrm{sec}$, and $72^{\circ} \mathrm{C}$ for $20 \mathrm{sec}$ and $1 \mathrm{cycle}$ at $72^{\circ} \mathrm{C}$ for $5 \mathrm{~min}$. The TCR DNA library from each sample was purified using a $1 \%$ agarose e-Gel and a unique band of $\sim 650 \mathrm{bp}$ in size was excised and extracted using QIAGEN gel extraction kit before being resuspended in RNase/DNase $\square$ free water.

A second nested PCR was performed using a nested template switching primer (5'CGCTCTTCCGATCTCTGGCAGTGGTATCAACG CAGAGTA) and either a $\operatorname{TCR} \alpha$ specific primer (5'TGCTCTTCCGATCTGACCACTGGATTTAGAGT CTCTCAGCTGGT) or TCR $\beta$ specific primer $\left(5^{\prime} \square\right.$ TCTCTGCTTCTGATGGCTCAAAC). The nested PCR assays were run using the NEB enzyme Q5 ${ }^{\circledR}$ Hot Start High-Fidelity (NEB, M0491) as follows: one cycle at $98^{\circ} \mathrm{C}$ for $30 \mathrm{sec} ; 10$ cycles at $98^{\circ} \mathrm{C}$ for 10 sec, $65^{\circ} \mathrm{C}$ for $10 \mathrm{sec}$, and $72^{\circ} \mathrm{C}$ for $20 \mathrm{sec}$ and $1 \mathrm{cycle}$ at $72^{\circ} \mathrm{C}$ for $5 \mathrm{~min}$. The TCR DNA library from each sample was purified using the $1 \%$ agarose e-Gel and a unique band of $\sim 550$ bp size was excised and extracted using QIAGEN gel extraction kit before being resuspended in RNase/DNase $\square$ free water. The $\operatorname{TCR} \alpha$ and TCR $\beta$ amplicons were "A-tailed" by adding adenosine to the 3 ' end of the amplicons. The amplicons where then ligated pCR4-topo plasmid between the M13F and M13R sequences and transformed into DH5 $\alpha$ Competent Cells following the manufactures protocols (Invitrogen, 18265-017). Up to 8 colonies were selected for each TCR $\alpha$ and TCR $\beta$ sequence for each of the KRAS ${ }^{\mathrm{G} 12 \mathrm{~V} / \mathrm{D}}$-specific $\mathrm{T}$ cell clones and DNA was isolated using a QIAprep
Spin Miniprep Kit (QIAGEN, 27104) and sequenced using the M13F and M13R primers. Clone-specific $\mathrm{V}$-gene and J-gene usage, as well as CDR3 sequences were extracted from sequencing data using IMGT/VQUEST and NCBI-IgBLAST (42-44).

Lentivirus production. To design recombinant TCRs for expression in host $\mathrm{T}$ cells, the recovered clonotypes of each KTCR were assembled into a bicistronic alpha-beta gene cassette, which was synthesized de novo and cloned into lentiviral transfer plasmids containing a downstream mStrawberry reporter gene. Replication-incompetent lentiviral particles were then generated to deliver the KTCR gene to healthy donor $\mathrm{CD}^{+} \mathrm{T}$ cells. To generate KTCR lentivirus, $80 \mu \mathrm{g}$ of each transfer plasmid was separately combined with $72 \mu \mathrm{g}$ of $\mathrm{pCMV}-\Delta \mathrm{R} 8.91$ and $8 \mu \mathrm{g}$ of pCMV-VSV-G plasmids. The DNA was combined with $430 \mu \mathrm{L}$ of TransIT-LT1 reagent (Mirus, MIR2305) in a mix made up to $8 \mathrm{~mL}$ with OptiMEM (Gibco, 31985062) and incubated for 30 minutes at room temperature. The $8 \mathrm{~mL}$ DNA/ TransIT-LT1 KTCR mix, was added to eight T75 flasks containing 80-90\% confluent 293T/17 [HEK 293T/17] (ATCC® CRL-11268 ${ }^{\mathrm{TM}}$ ) cells ( $1 \mathrm{~mL}$ of transfection mix per flask) along with $9 \mathrm{~mL}$ of supplemented RPMI-1640 media. Media was then removed 18-20 hours post-transfection and replaced with $5 \mu 1$ of supplemented RPMI-1640 media. The supplemented RPMI-1640 viral supernatant was then collected at 32, 44, and 56, hours post-transfection. To concentrate virus, supernatants were filtered through a $0.45 \mu \mathrm{M}$ filter and then centrifuged at $25,000 \mathrm{rpm}$ or $106,750 \mathrm{xg}$, for 90 minutes at $4^{\circ} \mathrm{C}$ (Optima XE-90, Beckman-Coulter with SW 32 Ti swinging bucket rotor) to pellet the virus. The virus was then resuspended in $1 \mathrm{~mL}$ OptiMEM. Viral titers were determined by testing (in duplicate) 1, 2, 4, 8, 16 , or $32 \mu \mathrm{L}$ of concentrated virus on $1 \times 10^{5} \mathrm{HeLa}$ $\left(\mathrm{ATCC}^{\circledR} \mathrm{CCL}^{\circledR}{ }^{\mathrm{TM}}\right.$ ) and $\mathrm{K} 562$ cells $\left(\mathrm{ATCC}^{\circledR}\right.$ CCL$243^{\mathrm{TM}}$ ) cells in 24 -well format with a final volume of $500 \mu \mathrm{L}$ of supplemented RPMI-1640 media. Transduction efficiency was determined by measuring the percentage $(\%)$ of fluorescent cells detected by flow cytometry. To prepare the cells for flow cytometry analysis, cells were centrifuged for 10 minutes at $400 \mathrm{xg}$ at $4^{\circ} \mathrm{C}$, the supernatant was 
Rive et al., 15 Jun 2020 - preprint copy - BioRxiv

discarded and cells were resuspensed in $500 \mu \mathrm{l}$ of cold FACS media with DAPI (1/1000, Sigma D9542). Acquisition was performed on the BD LSRFortessa cell analyser, and analyzed using FlowJo and GraphPad Prism (Figure S5).

Viral transduction. For transduction of $\mathrm{CD}^{+} \mathrm{T}$ cells, the appropriate number of PBMCs needed to obtain an MOI of 5 with $100 \mu \mathrm{L}$ of virus (based on previous titration calculations) were plated in 24-well format and incubated in supplemented RPMI-1640 media, with $300 \mathrm{U} / \mathrm{ml}$ rhIL-2 plus 100ng of anti-CD3 and 100ng anti-CD28 soluble antibodies. After 24 hours, $100 \mu \mathrm{L}$ virus was added to the cells. Cells were then incubated for $48 \mathrm{hrs}$ at $37^{\circ} \mathrm{C}$, washed, centrifuged at $400 \mathrm{xg}$ for $10 \mathrm{~min}$ at room temperature, and cells were resuspended in RPMI-1640 supplemented media with $400 \mathrm{U} / \mathrm{ml}$ rhIL-2 and an excess of allogeneic irradiated PBMCs feeders (50 Gy) in a final volume of $0.5 \mathrm{~mL}$. Cells were split every three days by moving $50 \%$ of the culture into a new well and adding supplemented RPMI-1640 media with rhIL-2 to give a final rhIL-2 concentration of $400 \mathrm{U} / \mathrm{ml}$ in a final volume of $0.5 \mathrm{~mL}$. After 2 weeks of expansion cell aliquots were stored down in cryopreservation media or sorted based on mStrawberry expression via flow cytometry. Sorted cells were expanded again as previously described before being used in the various in vitro assays.

The appropriate number of K562 cells needed to obtain an MOI of 5 with $100 \mu \mathrm{L}$ of HLA-A*02:01mStrawberry virus (based on previous titration calculations) were plated in 24-well format and incubated in supplemented RPMI-1640 media. After an expansion period, the K562-A*02:01 APCs were sorted based on mStrawberry expression via flow cytometry. Sorted cells were expanded cultured and expanded further before being used in in vitro assays.

Patient derived xenografts. The KTCRs were assessed in vivo using a PDX mouse model. Approval was granted by the Animal Care Committee at the University of British Columbia (certificate A19-0035) and the in vivo experiments were conducted in a blinded study by the Investigational Drug Program at BC Cancer. A number of KRAS ${ }^{\mathrm{G} 12 \mathrm{~V}}$ PDX samples had been identified following the methods used by
Bournet et al. (51). DNA was collected from the PDX samples using QIAamp DNA mini kit (Qiagen, 51304) and used in a TaqMan real-time PCR-based allelic discrimination assays (Life Technologies) with custom two allele-specific TaqMan MGB probes which were used to detect KRAS mutational status of the sample (51). We analyzed the KRAS ${ }^{\mathrm{G} 12 \mathrm{~V}}$ positive PDX samples and identified which samples also carried the HLA-A*02:01 allele by following the approach of Browning et al. (52). CB-17 SCID mice (CB17SC-M, TaconicBiosciences) had the relevant PDX tumour subcutaneously implanted into their lower right back. Once the implanted tumours reached an average size of $100 \mathrm{~mm}^{3}$, mice received an IV injection of $200 \mu \mathrm{l}$ of PBS containing either $0.5 \times 10^{6}$ KTCR 1 transduced CD8 $\mathrm{T}$ cells or $1 \times 10^{6}$ CD8 $\mathrm{T}$ cells, transduced with the mStrawberryexpressing control transfer vector. Tumours were measured using sterilized digital calipers and the volume was calculated using the modified ellipsoid formula Volume $\left(\mathrm{mm}^{3}\right)=1 / 2\left(\mathrm{LxW}^{2}\right)$ where length $(\mathrm{mm})$ was the greatest longitudinal measurement taken and the width $(\mathrm{mm})$ the greatest transverse measurement taken. The volume $\left(\mathrm{mm}^{3}\right)$ calculation was converted to a weight $(\mathrm{mg})$ measurement in order to calculate the tumour burden as a percentage of the mouse total weight. We also assessed the effectiveness the KTCR1 treatments by assessing mortality and morbidity during treatments. In particular, we assessed mice for signs of ill health based on body weight loss, change in appetite, behavioural changes such as altered gait, lethargy, tachypnea, pallor, jaundice, and gross manifestations of stress and other signs of ill health.

Data analysis. Flow cytometry analyses were performed using FlowJo V10.0.8. Sequence data handling was performed using Geneious v8.1.2. Other data handling and statistical analyses were performed using GraphPad Prism software version 8.0.0 for windows (GraphPad Software, California, USA). Results between control groups and test groups were compared using ANOVA analysis and tukey's multiple comparison test. The Mantel-Cox log rank test was used in the Kaplan-Meier analysis of survival probability analysis of PDX mice. ELISpot's were 
analyzed using an AID ELISpot reader and associated software (AID ELISpot Version 7.0).

\section{End Matter}

\section{Author Contributions and Notes}

R.A.H., C.M.R. an S.T. designed the study; G.B.M. and C.S.H. designed the MRM experiments, C.M.R, E.Y., C.S.H., S.D.B., G.S., L.D., N.M.N, C.W., J.H., A.L.M, and T.W., performed the research; J.M.K, D.T.Y., G.B.M. D.J.R.and D.S. and R.A.H provided supervision; R.A.H and C.M.R wrote the manuscript. All authors reviewed and edited the manuscript.

R.A.H., C.M.R., and S.T. are named inventors on patent application PCT/2020/050715 filed by the BC Provinical Health Services Authority.

\section{Acknowledgments}

We thank the BioCanRx network, the BC Cancer Foundation, and the Leon Judah Blackmore Foundation for their ongoing support for this research. We thank the Investigational Drug Program at the BC Cancer Research Institute and the Pancreas Centre $\mathrm{BC}$ to the in vivo proportion of this body of work. The authors acknowledge the American Association for Cancer Research and its support in the development of the AACR Project GENIE registry as well as members of the consortium for their commitment to data sharing. The MR1 tetramer technology was developed jointly by Dr. James McCluskey, Dr. Jamie Rossjohn, and Dr. David Fairlie, and tetramers for $\mathrm{KRAS}^{\mathrm{G} 12 \mathrm{~V}}, \mathrm{KRAS}^{\mathrm{G} 12 \mathrm{D}}$, and KRAS $^{\text {WT }}$ was produced by the NIH Tetramer Core Facility as permitted to be distributed by the University of Melbourne. 
bioRxiv preprint doi: https://doi.org/10.1101/2020.06.15.149021; this version posted June 16, 2020. The copyright holder for this preprint

(which was not certified by peer review) is the author/funder, who has granted bioRxiv a license to display the preprint in perpetuity. It is made available under aCC-BY-NC-ND 4.0 International license.

Rive et al., 15 Jun 2020 - preprint copy - BioRxiv

\section{References}

1. B. V. Sinn, J. K. Striefler, M. A. Rudl, A. Lehmann, M. Bahra, C. Denkert, M. Sinn, J. Stieler, F. Klauschen, J. Budczies, W. Weichert, A. Stenzinger, C. Kamphues, M. Dietel, H. Riess, KRAS Mutations in Codon 12 or 13 Are Associated With Worse Prognosis in Pancreatic Ductal Adenocarcinoma. Pancreas 43, (2014).

2. D. A. Eberhard, B. E. Johnson, L. C. Amler, A. D. Goddard, S. L. Heldens, R. S. Herbst, W. L. Ince, P. A. Janne, T. Januario, D. H. Johnson, P. Klein, V. A. Miller, M. A. Ostland, D. A. Ramies, D. Sebisanovic, J. A. Stinson, Y. R. Zhang, S. Seshagiri, K. J. Hillan, Mutations in the epidermal growth factor receptor and in KRAS are predictive and prognostic indicators in patients with non-small-cell lung cancer treated with chemotherapy alone and in combination with erlotinib. Journal of clinical oncology : official journal of the American Society of Clinical Oncology 23, 59005909 (2005).

3. J. A. Kern, R. J. Slebos, B. Top, S. Rodenhuis, D. Lager, R. A. Robinson, D. Weiner, D. A. Schwartz, C-erbB-2 expression and codon $12 \mathrm{~K}$-ras mutations both predict shortened survival for patients with pulmonary adenocarcinomas. J Clin Invest 93, 516-520 (1994).

4. R. Rosell, M. Monzo, F. Molina, E. Martinez, A. Pifarre, I. Moreno, J. L. Mate, J. M. d. Anta, M. Sanchez, A. Font, K-ras genotypes and prognosis in non-small-cell lung cancer. Annals of Oncology 6, S15-S20 (1995).

5. J. M. Siegfried, A. T. Gillespie, R. Mera, T. J. Casey, P. Keohavong, J. R. Testa, J. D. Hunt, Prognostic value of specific KRAS mutations in lung adenocarcinomas. Cancer Epidemiol Biomarkers Prev 6, 841-847 (1997).

6. E. M. Silini, F. Bosi, E. Solcia, R. Fiocca, N. S. Pellegata, G. N. Ranzani, G. Volpato, A. Romano, S. Nazari, C. Tinelli, K-ras gene mutations: an unfavorable prognostic marker in stage I lung adenocarcinoma. Virchows Archiv 424, 367-373 (1994).

7. R. J. C. Slebos, R. E. Kibbelaar, O. Dalesio, A. Kooistra, J. Stam, C. J. L. M. Meijer, S. S. Wagenaar, R. G. J. R. A. Vanderschueren, N. van Zandwijk, W. J. Mooi, J. L. Bos, S. Rodenhuis, K-ras Oncogene Activation as a Prognostic Marker in Adenocarcinoma of the Lung. New England Journal of Medicine 323, 561-565 (1990).

8. A. P. G. Consortium, AACR Project GENIE: Powering Precision Medicine through an International Consortium. Cancer Discov 7, 818-831 (2017).

9. P. Bailey, D. K. Chang, K. Nones, A. L. Johns, A. M. Patch, M. C. Gingras, D. K. Miller, A. N. Christ, T. J. Bruxner, M. C. Quinn, C. Nourse, L. C. Murtaugh, I. Harliwong, S. Idrisoglu, S. Manning, E. Nourbakhsh, S. Wani, L. Fink, O. Holmes, V. Chin, M. J. Anderson, S. Kazakoff, C. Leonard, F. Newell, N. Waddell, S. Wood, Q. Xu, P. J. Wilson, N. Cloonan, K. S. Kassahn, D. Taylor, K. Quek, A. Robertson, L. Pantano, L. Mincarelli, L. N. Sanchez, L. Evers, J. Wu, M. Pinese, M. J. Cowley, M. D. Jones, E. K. Colvin, A. M. Nagrial, E. S. Humphrey, L. A. Chantrill, A. Mawson, J. Humphris, A. Chou, M. Pajic, C. J. Scarlett, A. V. Pinho, M. Giry-Laterriere, I. Rooman, J. S. Samra, J. G. Kench, J. A. Lovell, N. D. Merrett, C. W. Toon, K. Epari, N. Q. Nguyen, A. Barbour, N. Zeps, K. Moran-Jones, N. B. Jamieson, J. S. Graham, F. Duthie, K. Oien, J. Hair, R. Grützmann, A. Maitra, C. A. Iacobuzio-Donahue, C. L. Wolfgang, R. A. Morgan, R. T. Lawlor, V. Corbo, C. Bassi, B. Rusev, P. Capelli, R. Salvia, G. Tortora, D. Mukhopadhyay, G. M. Petersen, D. M. Munzy, W. E. Fisher, S. A. Karim, J. R. Eshleman, R. H. Hruban, C. Pilarsky, J. P. Morton, O. J. Sansom, A. Scarpa, E. A. Musgrove, U. M. Bailey, O. Hofmann, R. L. Sutherland, D. A. Wheeler, A. J. Gill, R. A. Gibbs, J. V. Pearson, N. Waddell, A. V. Biankin, S. M. Grimmond, Genomic analyses identify molecular subtypes of pancreatic cancer. Nature 531, 47-52 (2016).

10. A. V. Biankin, N. Waddell, K. S. Kassahn, M. C. Gingras, L. B. Muthuswamy, A. L. Johns, D. K. Miller, P. J. Wilson, A. M. Patch, J. Wu, D. K. Chang, M. J. Cowley, B. B. Gardiner, S. Song, I. Harliwong, S. Idrisoglu, C. Nourse, E. Nourbakhsh, S. Manning, S. Wani, M. Gongora, M. Pajic, C. J. Scarlett, A. J. Gill, A. V. Pinho, I. Rooman, M. Anderson, O. Holmes, C. Leonard, D. Taylor, S. Wood, Q. Xu, K. Nones, J. L. Fink, A. Christ, T. Bruxner, N. Cloonan, G. Kolle, F. Newell, M. Pinese, R. S. Mead, J. L. Humphris, W. Kaplan, M. D. Jones, E. K. Colvin, A. M. Nagrial, E. S. Humphrey, A. Chou, V. T. Chin, L. A. Chantrill, A. Mawson, J. S. Samra, J. G. Kench, J. A. Lovell, R. J. Daly, N. D. Merrett, C. Toon, K. Epari, N. Q. Nguyen, A. Barbour, N. Zeps, N. Kakkar, F. Zhao, Y. Q. Wu, M. Wang, D. M. Muzny, W. E. Fisher, F. C. Brunicardi, S. E. Hodges, J. G. Reid, J. Drummond, K. Chang, Y. Han, L. R. Lewis, H. Dinh, C. J. Buhay, T. Beck, L. Timms, M. Sam, K. Begley, A. Brown, D. Pai, A. Panchal, N. Buchner, R. De Borja, R. E. Denroche, C. K. Yung, S. Serra, N. Onetto, D. Mukhopadhyay, M. S. Tsao, P. A. Shaw, G. M. Petersen, S. Gallinger, R. H. Hruban, A. Maitra, C. A. Iacobuzio-Donahue, R. D. Schulick, C. L. Wolfgang, R. A. Morgan, R. T. Lawlor, P. Capelli, V. Corbo, M. Scardoni, G. Tortora, M. A. Tempero, K. M. Mann, N. A. Jenkins, P. A. Perez-Mancera, D. J. Adams, D. A. Largaespada, L. F. A. Wessels, A. G. Rust, L. D. Stein, D. A. Tuveson, N. G. Copeland, E. A. Musgrove, A. Scarpa, J. R. Eshleman, T. J. Hudson, R. L. Sutherland, D. A. Wheeler, J. V. Pearson, J. D. McPherson, R. A. Gibbs, S. M. Grimmond, Pancreatic cancer genomes reveal aberrations in axon guidance pathway genes. Nature 491, 399-405 (2012). 
bioRxiv preprint doi: https://doi.org/10.1101/2020.06.15.149021; this version posted June 16, 2020. The copyright holder for this preprint

(which was not certified by peer review) is the author/funder, who has granted bioRxiv a license to display the preprint in perpetuity. It is made available under aCC-BY-NC-ND 4.0 International license.

Rive et al., DD MMM YYYY - preprint copy - BioRxiv

11. S. Jones, X. Zhang, D. W. Parsons, J. C. Lin, R. J. Leary, P. Angenendt, P. Mankoo, H. Carter, H. Kamiyama, A. Jimeno, S. M. Hong, B. Fu, M. T. Lin, E. S. Calhoun, M. Kamiyama, K. Walter, T. Nikolskaya, Y. Nikolsky, J. Hartigan, D. R. Smith, M. Hidalgo, S. D. Leach, A. P. Klein, E. M. Jaffee, M. Goggins, A. Maitra, C. IacobuzioDonahue, J. R. Eshleman, S. E. Kern, R. H. Hruban, R. Karchin, N. Papadopoulos, G. Parmigiani, B. Vogelstein, V. E. Velculescu, K. W. Kinzler, Core signaling pathways in human pancreatic cancers revealed by global genomic analyses. Science 321, 1801-1806 (2008).

12. C. Almoguera, D. Shibata, K. Forrester, J. Martin, N. Arnheim, M. Perucho, Most human carcinomas of the exocrine pancreas contain mutant c-K-ras genes. Cell 53, 549-554 (1988).

13. J. L. Bos, E. R. Fearon, S. R. Hamilton, M. Verlaan-de Vries, J. H. van Boom, A. J. van der Eb, B. Vogelstein, Prevalence of ras gene mutations in human colorectal cancers. Nature 327, 293-297 (1987).

14. S. Jančík, J. Drábek, D. Radzioch, M. Hajdúch, Clinical Relevance of KRAS in Human Cancers. Journal of Biomedicine and Biotechnology 2010, 13 (2010).

15. C. P. Vaughn, S. D. ZoBell, L. V. Furtado, C. L. Baker, W. S. Samowitz, Frequency of KRAS, BRAF, and NRAS mutations in colorectal cancer. Genes, Chromosomes and Cancer 50, 307-312 (2011).

16. P. H. Seeburg, W. W. Colby, D. J. Capon, D. V. Goeddel, A. D. Levinson, Biological properties of human c-Ha-ras1 genes mutated at codon 12. Nature 312, 71-75 (1984).

17. S. Bhattacharya, M. A. Socinski, T. F. Burns, KRAS mutant lung cancer: progress thus far on an elusive therapeutic target. Clinical and Translational Medicine 4, 35 (2015).

18. P. Liu, Y. Wang, X. Li, Targeting the untargetable KRAS in cancer therapy. Acta Pharmaceutica Sinica B 9, 871-879 (2019).

19. D. Zeitouni, Y. Pylayeva-Gupta, C. J. Der, K. L. Bryant, KRAS Mutant Pancreatic Cancer: No Lone Path to an Effective Treatment. Cancers (Basel) 8, (2016).

20. S. I. Abrams, S. N. Khleif, E. S. Bergmann-Leitner, J. A. Kantor, Y. Chung, J. M. Hamilton, J. Schlom, Generation of stable CD4+ and CD8+ T cell lines from patients immunized with ras oncogene-derived peptides reflecting codon 12 mutations. Cell Immunol 182, 137-151 (1997).

21. M. K. Gjertsen, J. Bjorheim, I. Saeterdal, J. Myklebust, G. Gaudernack, Cytotoxic CD4+ and CD8+ T lymphocytes, generated by mutant $\mathrm{p} 21$-ras (12Val) peptide vaccination of a patient, recognize 12Val-dependent nested epitopes present within the vaccine peptide and kill autologous tumour cells carrying this mutation. International journal of cancer 72, 784-790 (1997).

22. S. D. Brown, R. L. Warren, E. A. Gibb, S. D. Martin, J. J. Spinelli, B. H. Nelson, R. A. Holt, Neo-antigens predicted by tumor genome meta-analysis correlate with increased patient survival. Genome research 24, 743-750 (2014).

23. M. S. Rooney, S. A. Shukla, C. J. Wu, G. Getz, N. Hacohen, Molecular and genetic properties of tumors associated with local immune cytolytic activity. Cell 160, 48-61 (2015).

24. V. Thorsson, D. L. Gibbs, S. D. Brown, D. Wolf, D. S. Bortone, T. H. Ou Yang, E. Porta-Pardo, G. F. Gao, C. L. Plaisier, J. A. Eddy, E. Ziv, A. C. Culhane, E. O. Paull, I. K. A. Sivakumar, A. J. Gentles, R. Malhotra, F. Farshidfar, A. Colaprico, J. S. Parker, L. E. Mose, N. S. Vo, J. Liu, Y. Liu, J. Rader, V. Dhankani, S. M. Reynolds, R. Bowlby, A. Califano, A. D. Cherniack, D. Anastassiou, D. Bedognetti, Y. Mokrab, A. M. Newman, A. Rao, K. Chen, A. Krasnitz, H. Hu, T. M. Malta, H. Noushmehr, C. S. Pedamallu, S. Bullman, A. I. Ojesina, A. Lamb, W. Zhou, H. Shen, T. K. Choueiri, J. N. Weinstein, J. Guinney, J. Saltz, R. A. Holt, C. S. Rabkin, A. J. Lazar, J. S. Serody, E. G. Demicco, M. L. Disis, B. G. Vincent, I. Shmulevich, The Immune Landscape of Cancer. Immunity 48, 812-830.e814 (2018).

25. R. L. Warren, R. A. Holt, A census of predicted mutational epitopes suitable for immunologic cancer control. Human Immunology 71, 245-254 (2010).

26. Q. J. Wang, Z. Yu, K. Griffith, K. Hanada, N. P. Restifo, J. C. Yang, Identification of T-cell Receptors Targeting KRAS-Mutated Human Tumors. Cancer immunology research 4, 204-214 (2016).

27. E. Tran, P. F. Robbins, Y.-C. Lu, T. D. Prickett, J. J. Gartner, L. Jia, A. Pasetto, Z. Zheng, S. Ray, E. M. Groh, I. R. Kriley, S. A. Rosenberg, T-Cell Transfer Therapy Targeting Mutant KRAS in Cancer. New England Journal of Medicine 375, 2255-2262 (2016).

28. G. Gorochov, J. Lustgarten, T. Waks, G. Gross, Z. Eshhar, Functional assembly of chimeric T-cell receptor chains. International journal of cancer. Supplement = Journal international du cancer. Supplement 7, 53-57 (1992).

29. S. Boegel, M. Löwer, T. Bukur, U. Sahin, J. C. Castle, A catalog of HLA type, HLA expression, and neo-epitope candidates in human cancer cell lines. Oncoimmunology 3, e954893 (2014).

30. S. D. Martin, D. A. Wick, J. S. Nielsen, N. Little, R. A. Holt, B. H. Nelson, A library-based screening method identifies neoantigen-reactive T cells in peripheral blood prior to relapse of ovarian cancer. Oncoimmunology 7 , e1371895-e1371895 (2017). 
bioRxiv preprint doi: https://doi.org/10.1101/2020.06.15.149021; this version posted June 16, 2020. The copyright holder for this preprint

(which was not certified by peer review) is the author/funder, who has granted bioRxiv a license to display the preprint in perpetuity. It is made available under aCC-BY-NC-ND 4.0 International license.

Rive et al., 15 Jun 2020 - preprint copy version 1 - BioRxiv

31. D. A. Wick, J. R. Webb, J. S. Nielsen, S. D. Martin, D. R. Kroeger, K. Milne, M. Castellarin, K. Twumasi-Boateng, P. H. Watson, R. A. Holt, B. H. Nelson, Surveillance of the tumor mutanome by T cells during progression from primary to recurrent ovarian cancer. Clin Cancer Res 20, 1125-1134 (2014).

32. R. P. Jones, P. A. Sutton, J. P. Evans, R. Clifford, A. McAvoy, J. Lewis, A. Rousseau, R. Mountford, D. McWhirter, H. Z. Malik, Specific mutations in KRAS codon 12 are associated with worse overall survival in patients with advanced and recurrent colorectal cancer. British Journal of Cancer 116, 923-929 (2017).

33. J. D. Freeman, R. L. Warren, J. R. Webb, B. H. Nelson, R. A. Holt, Profiling the T-cell receptor beta-chain repertoire by massively parallel sequencing. Genome research 19, 1817-1824 (2009).

34. C. M. Rive, E. Yung, L. Dreolini, D. J. Woodsworth, R. A. Holt, Selective B cell depletion upon infusion of replication-incompetent anti-CD19 CAR lentivirus. bioRxiv, 2020.2005.2015.098335 (2020).

35. A. J. Corbett, S. B. Eckle, R. W. Birkinshaw, L. Liu, O. Patel, J. Mahony, Z. Chen, R. Reantragoon, B. Meehan, H. Cao, N. A. Williamson, R. A. Strugnell, D. Van Sinderen, J. Y. Mak, D. P. Fairlie, L. Kjer-Nielsen, J. Rossjohn, J. McCluskey, T-cell activation by transitory neo-antigens derived from distinct microbial pathways. Nature 509, 361365 (2014).

36. S. Turcotte, A. Gros, E. Tran, C.-C. R. Lee, J. R. Wunderlich, P. F. Robbins, S. A. Rosenberg, Tumor-reactive CD8+ $\mathrm{T}$ cells in metastatic gastrointestinal cancer refractory to chemotherapy. Clinical cancer research : an official journal of the American Association for Cancer Research 20, 331-343 (2014).

37. J. Canon, K. Rex, A. Y. Saiki, C. Mohr, K. Cooke, D. Bagal, K. Gaida, T. Holt, C. G. Knutson, N. Koppada, B. A. Lanman, J. Werner, A. S. Rapaport, T. San Miguel, R. Ortiz, T. Osgood, J.-R. Sun, X. Zhu, J. D. McCarter, L. P. Volak, B. E. Houk, M. G. Fakih, B. H. O’Neil, T. J. Price, G. S. Falchook, J. Desai, J. Kuo, R. Govindan, D. S. Hong, W. Ouyang, H. Henary, T. Arvedson, V. J. Cee, J. R. Lipford, The clinical KRAS(G12C) inhibitor AMG 510 drives anti-tumour immunity. Nature 575, 217-223 (2019).

38. NCT03600883, A Phase 1/2, Study Evaluating the Safety, Tolerability, PK, and Efficacy of AMG 510 in Subjects With Solid Tumors With a Specific KRAS Mutation., (2019).

39. AMG 510 Ethnic Sensitivity Study (2020).

40. Study to Compare AMG 510 "Proposed INN Sotorasib" With Docetaxel in Non Small Cell Lung Cancer (NSCLC) (2020).

41. AMG 510 (pINN) Sotorasib Activity in Subjects With Advanced Solid Tumors With KRAS p.G12C Mutation (2019).

42. V. Giudicelli, D. Chaume, M. P. Lefranc, IMGT/V-QUEST, an integrated software program for immunoglobulin and T cell receptor V-J and V-D-J rearrangement analysis. Nucleic Acids Res 32, W435-440 (2004).

43. V. Giudicelli, M. P. Lefranc, IMGT/junctionanalysis: IMGT standardized analysis of the V-J and V-D-J junctions of the rearranged immunoglobulins (IG) and T cell receptors (TR). Cold Spring Harbor protocols 2011, 716-725 (2011).

44. J. Ye, N. Ma, T. L. Madden, J. M. Ostell, IgBLAST: an immunoglobulin variable domain sequence analysis tool. Nucleic acids research 41, W34-W40 (2013).

45. Activities at the Universal Protein Resource (UniProt). Nucleic Acids Res 42, D191-198 (2014).

46. L. K. Pino, B. C. Searle, J. G. Bollinger, B. Nunn, B. MacLean, M. J. MacCoss, The Skyline ecosystem: Informatics for quantitative mass spectrometry proteomics. Mass Spectrom Rev 39, 229-244 (2020).

47. P. J. Boersema, R. Raijmakers, S. Lemeer, S. Mohammed, A. J. Heck, Multiplex peptide stable isotope dimethyl labeling for quantitative proteomics. Nat Protoc 4, 484-494 (2009).

48. Freeman JD, Warren RL, Webb JR, Nelson BH, Holt RA. Profiling the T-cell receptor beta-chain repertoire by massively parallel sequencing. Genome Res 19,1817-1824 (2009). doi:10.1101/gr.092924.109

49. M. F. Quigley, J. R. Almeida, D. A. Price, D. C. Douek, Unbiased molecular analysis of T cell receptor expression using template-switch anchored RT-PCR. Current protocols in immunology Chapter 10, Unit10.33 (2011).

50. X. Yu, J. R. Almeida, S. Darko, M. van der Burg, S. S. DeRavin, H. Malech, A. Gennery, I. Chinn, M. L. Markert, D. C. Douek, J. D. Milner, Human syndromes of immunodeficiency and dysregulation are characterized by distinct defects in T-cell receptor repertoire development. Journal of Allergy and Clinical Immunology 133, 1109-1115.e1114 (2014).

51. B. Bournet, A. Vignolle-Vidoni, D. Grand, C. Roques, F. Breibach, J. Cros, F. Muscari, N. Carrère, J. Selves, P. Cordelier, L. Buscail, Endoscopic ultrasound-guided fine-needle aspiration plus KRAS and GNAS mutation in malignant intraductal papillary mucinous neoplasm of the pancreas. Endosc Int Open 4, E1228-E1235 (2016).

52. M. J. Browning, P. Krausa, A. Rowan, D. C. Bicknell, J. G. Bodmer, W. F. Bodmer, Tissue typing the HLA-A locus from genomic DNA by sequence-specific PCR: comparison of HLA genotype and surface expression on colorectal tumor cell lines. Proceedings of the National Academy of Sciences 90, 2842 (1993). 
bioRxiv preprint doi: https://doi.org/10.1101/2020.06.15.149021; this version posted June 16, 2020. The copyright holder for this preprint (which was not certified by peer review) is the author/funder, who has granted bioRxiv a license to display the preprint in perpetuity. It is made available under aCC-BY-NC-ND 4.0 International license.

Rive et al., DD MMM YYYY - preprint copy - BioRxiv

\section{Tables \& Figures:}

TCR $\alpha \beta$ variable

TRBV 19*01

TRBV 04-1*01

chains

TRAV 27*01

TCR1 (KRAS $\left.{ }^{\mathrm{G} 12 \mathrm{~V}}\right) \quad \mathrm{TCR} 3\left(\mathrm{KRAS}^{\mathrm{G} 12 \mathrm{D}}\right)$

TRAV 13-2*01

TCR2 (KRAS $\left.{ }^{\mathrm{G} 12 \mathrm{D}}\right)$

Table 1: Neoepitope specificities and alpha/beta chain identities of TCRs 1, 2 and 3 (derived from T cell clones 1, 2 and 3, respectively). 

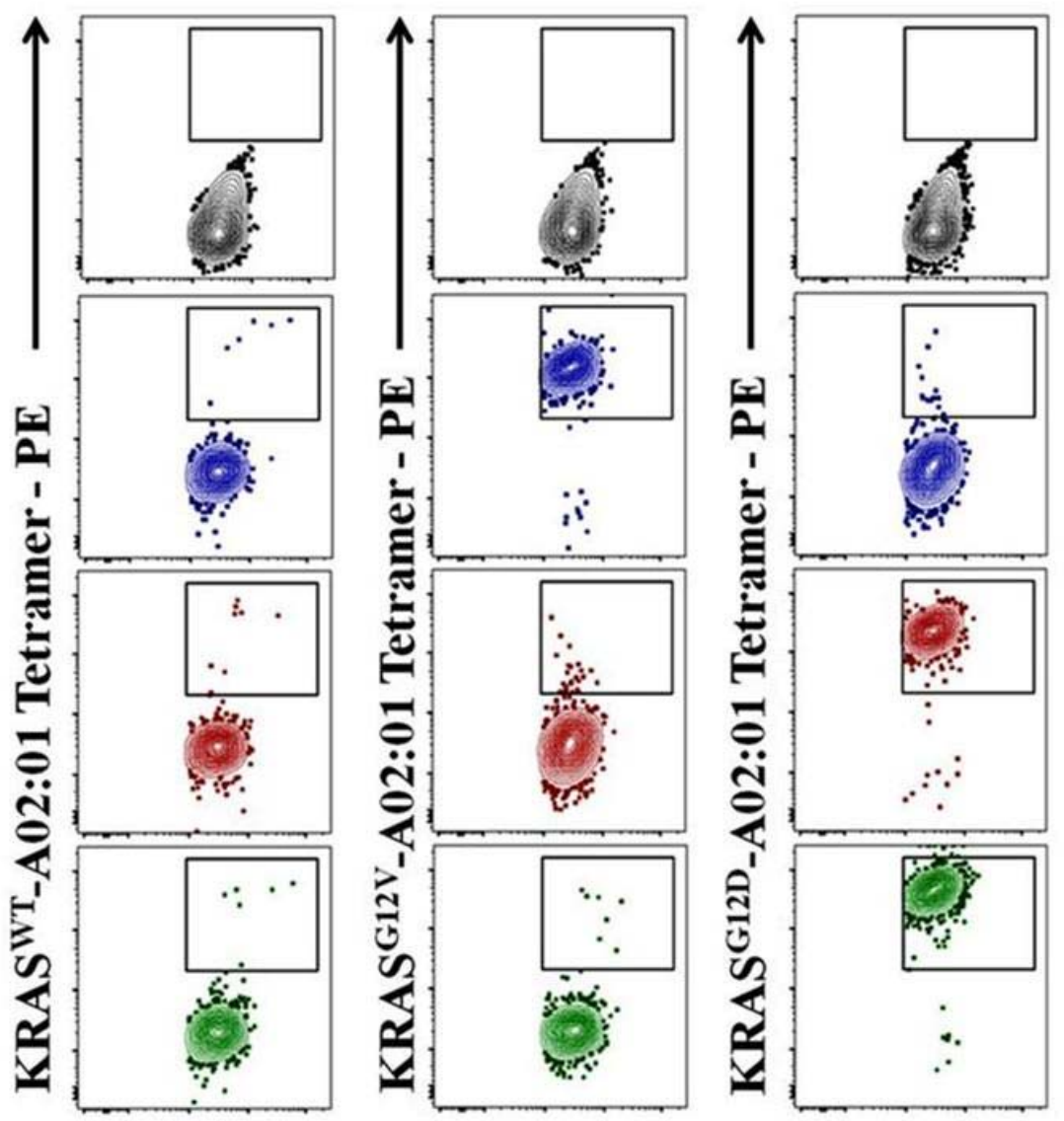

Negative control T cells

CD3 - eFluor 450

Figure 1: Tetramer analysis of HLA-A $* 02: 01-$ restricted $\mathrm{KRAS}^{\mathbf{G 1 2 V} / \mathbf{D}}$ specific $\mathbf{T}$ cell clones. Monoclonal CD8+ $\mathrm{T}$ cells (blue) were stained strongly by the $\mathrm{KRAS}^{\mathrm{G} 12 \mathrm{~V}} / \mathrm{A} * 02: 01$ tetramer $(99.1 \%)$ and minimally $(<2 \%)$ by the KRAS $^{\mathrm{G} 12 \mathrm{D}}$ tetramer and KRAS ${ }^{\mathrm{wt}}$ tetramer. The two other monoclonal CD8+ T cells (red and green) stained strongly by the $\mathrm{KRAS}^{\mathrm{G} 12 \mathrm{D}} / \mathrm{A} * 02: 01$ tetramer $\left(98.8 \%\right.$ and $97.5 \%$, respectively) and minimally $(<2 \%)$ by the $\mathrm{KRAS}^{\mathrm{G} 12 \mathrm{~V}}$ and $\mathrm{KRAS}^{\mathrm{wt}}$ tetramers. The flow gating protocol is outlined in Figure S3. 
bioRxiv preprint doi: https://doi.org/10.1101/2020.06.15.149021; this version posted June 16, 2020. The copyright holder for this preprint (which was not certified by peer review) is the author/funder, who has granted bioRxiv a license to display the preprint in perpetuity. It is made available under aCC-BY-NC-ND 4.0 International license.

Rive et al., DD MMM YYYY - preprint copy - BioRxiv

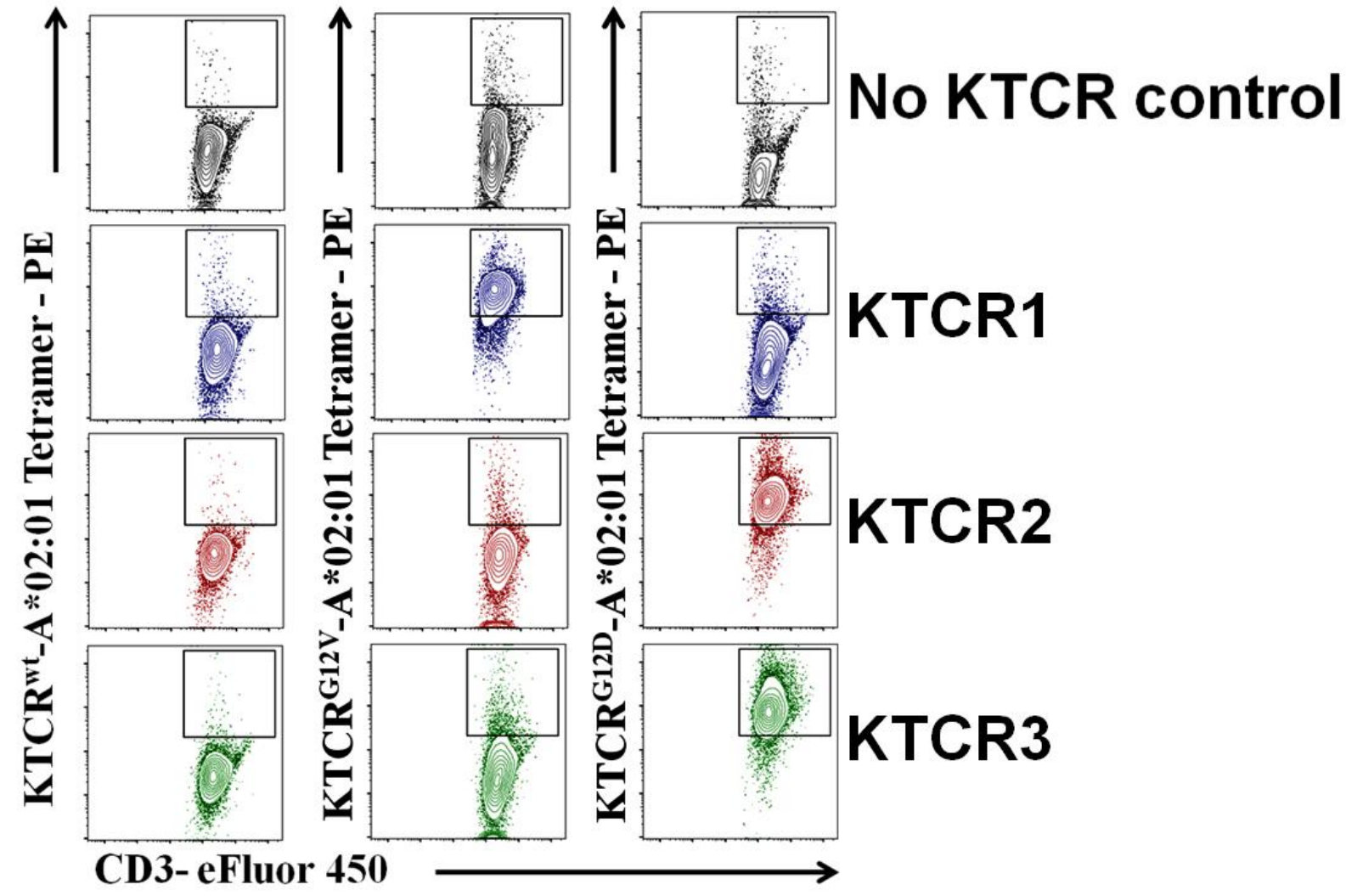

Figure 2: Tetramer analysis of KTCR-transduced CD8+ T cells. KTCR1 (blue) transduced CD3+CD8+ T cells (blue) were stained strongly by the $\mathrm{KRAS}^{\mathrm{G} 12 \mathrm{~V}} / \mathrm{A}^{*} 02: 01$ tetramer $(83.7 \%)$ and minimally $(<5 \%)$ by $\mathrm{KRAS}^{\mathrm{G} 12 \mathrm{D}}$ and KRAS $^{\text {wt }}$ tetramers. KTCR2 (red) and KTCR3 (green) transduced CD3+CD8+ T cells were stained strongly by the $\operatorname{KRAS}^{\mathrm{G} 12 \mathrm{D}} / \mathrm{A}^{*} 02: 01$ tetramer $\left(89.3 \%\right.$ and $88.7 \%$, respectively) and minimally $(<5 \%)$ by $\mathrm{KRAS}^{\mathrm{G} 12 \mathrm{~V}}$ and $\mathrm{KRAS}^{\mathrm{wt}}$ tetramers. The flow gating protocol is outlined in Figure S3. 
A

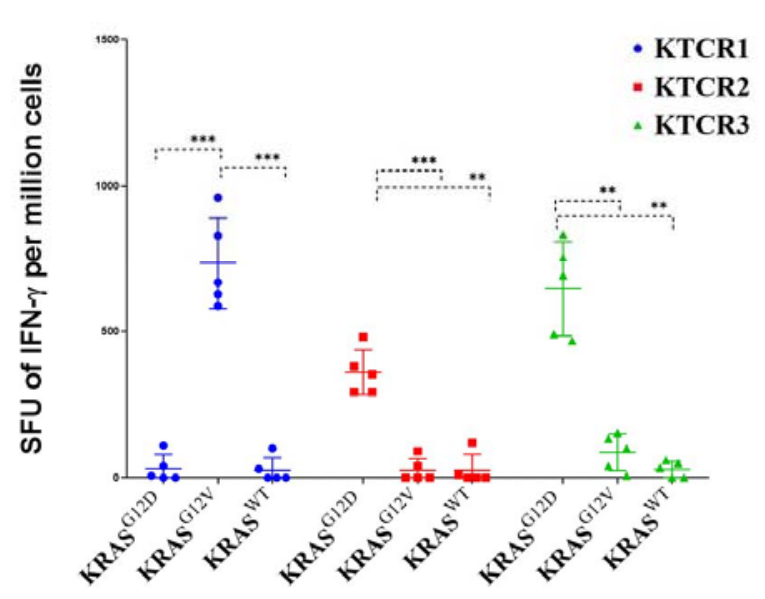

$\mathbf{B}$

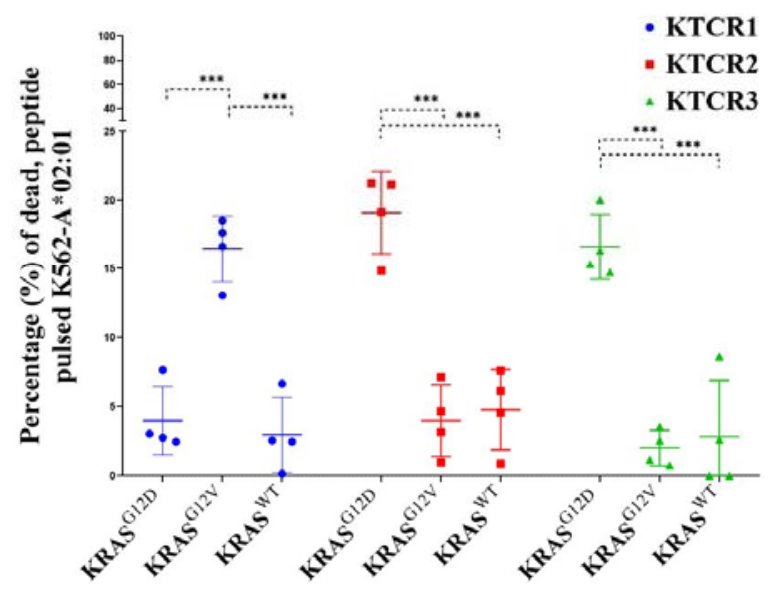

Figure 3: In vitro analysis of KTCR transduced $\mathrm{CD8}^{+} \mathbf{T}$ cells. Results from IFN- $\gamma$ ELISpot assays (A) and cytolytic assays (B), evaluating KTCR1 (blue circles), KTCR2 (red squares), and KTCR3 (green triangles) activity against peptide pulsed K562A*02:01 target cells. (**p $<0.01$ and $* * * p=0.001$; ANOVA and Tukey's multiple comparison test)The flow gating protocol is outlined in Figure $\mathbf{S 4}$. 
Rive et al., DD MMM YYYY - preprint copy - BioRxiv
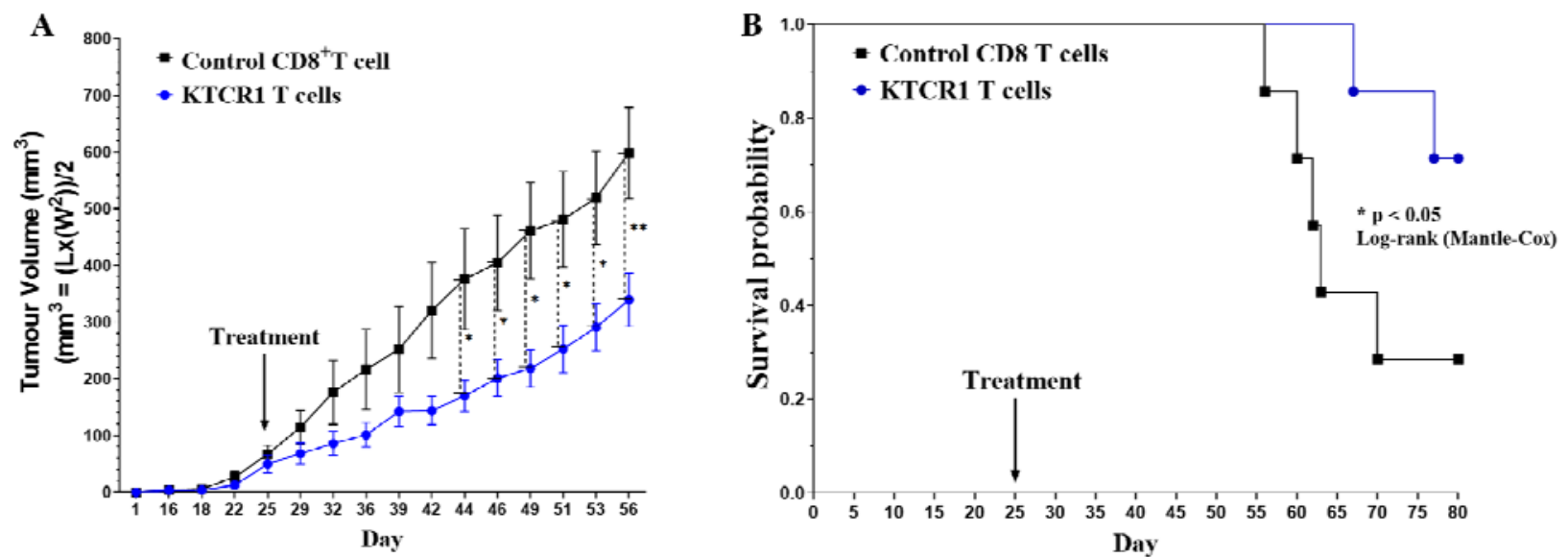

Figure 4: Testing of HLA-A*02:01-restricted KRAS ${ }^{\mathrm{G12V}}$ specific TCR reconstituted T cells in vivo. Figure 4A: Treatment with KTCR1-transduced $\mathrm{CD}^{+} \mathrm{T}$ cells (blue circles) reduced tumour growth when compared to the mice treated with control $\mathrm{CD} 8^{+} \mathrm{T}$ cells (black squares) $(\mathrm{n}=7)$. Significantly reduced growth was seen from days $44(* \mathrm{p} \leq 0.020)$, to completion of the experiment on day $56(* * \mathrm{p} \leq 0.002)$ (ANOVA, $\mathrm{p}<0.001$ and Tukey's multiple comparison test). Figure 4B. Kaplan-Meier analysis of survival probability of mice treated with KTCR1 CD8 ${ }^{+} \mathrm{T}$ cells (blue circles) compared to mice treated with the control $\mathrm{CD}^{+} \mathrm{T}$ cells (black squares) $\left(\mathrm{n}=7\right.$; ${ }^{*} \mathrm{p}<0.05$; mantel-Cox log-rank test). 
bioRxiv preprint doi: https://doi.org/10.1101/2020.06.15.149021; this version posted June 16, 2020. The copyright holder for this preprint (which was not certified by peer review) is the author/funder, who has granted bioRxiv a license to display the preprint in perpetuity. It is made available under aCC-BY-NC-ND 4.0 International license.

Rive et al., 15 Jun 2020 - preprint copy version 1 - BioRxiv

\section{$\underline{\text { Supplementary }}$}

\begin{tabular}{|c|c|c|c|c|c|}
\hline & \multicolumn{2}{|c|}{$\underline{\text { Transitions }}$} & \multirow[b]{2}{*}{$\frac{\text { Dwell time }}{\underline{\text { (msec) }}}$} & \multirow[b]{2}{*}{$\begin{array}{l}\text { Peptide sequence, fragment position, and } \\
\underline{\text { labeling }}\end{array}$} & \multirow[b]{2}{*}{$\begin{array}{l}\text { Collision } \\
\text { energy }\end{array}$} \\
\hline & $\frac{\text { Product }}{\underline{\text { ion }}}$ & $\frac{\text { Fragment }}{\underline{\text { ion }}}$ & & & \\
\hline \multirow{10}{*}{$\begin{array}{l}\text { KRAS }^{\mathrm{wt}} \\
\underline{\text { KLVVVGAGGV) }}\end{array}$} & $\underline{481.8461}$ & $\underline{459.2562}$ & $\underline{45}$ & KRAS-WT.KLVVVGAGGV.+2y6.dimethyl-medium & $\underline{25}$ \\
\hline & $\underline{481.8461}$ & $\underline{360.1878}$ & $\underline{45}$ & KRAS-WT.KLVVVGAGGV.+2y5.dimethyl-medium & $\underline{25}$ \\
\hline & $\underline{481.8461}$ & $\underline{232.1292}$ & $\underline{45}$ & KRAS-WT.KLVVVGAGGV.+2y3.dimethyl-medium & $\underline{25}$ \\
\hline & $\underline{481.8461}$ & $\underline{504.4359}$ & $\underline{45}$ & KRAS-WT.KLVVVGAGGV.+2b4.dimethyl-medium & $\underline{25}$ \\
\hline & $\underline{481.8461}$ & $\underline{788.5844}$ & $\underline{45}$ & KRAS-WT.KLVVVGAGGV.+2b8.dimethyl-medium & $\underline{25}$ \\
\hline & $\underline{477.821}$ & $\underline{459.2562}$ & $\underline{45}$ & KRAS-WT.KLVVVGAGGV.+2y6.dimethyl-light & $\underline{25}$ \\
\hline & $\underline{477.821}$ & $\underline{360.1878}$ & $\underline{45}$ & KRAS-WT.KLVVVGAGGV.+2y5.dimethyl-light & $\underline{25}$ \\
\hline & $\underline{477.821}$ & $\underline{232.1292}$ & $\underline{45}$ & KRAS-WT.KLVVVGAGGV.+2y3.dimethyl-light & $\underline{25}$ \\
\hline & $\underline{477.821}$ & $\underline{496.3857}$ & $\underline{45}$ & KRAS-WT.KLVVVGAGGV.+2b4.dimethyl-light & $\underline{25}$ \\
\hline & $\underline{477.821}$ & $\underline{780.5342}$ & $\underline{45}$ & KRAS-WT.KLVVVGAGGV.+2b8.dimethyl-light & $\underline{25}$ \\
\hline \multirow{14}{*}{$\frac{\text { KRAS }^{\mathrm{G12D}}}{\underline{\left(\mathrm{KLVVVG}^{\prime} \mathrm{ADGV}\right)}}$} & $\underline{510.8488}$ & $\underline{517.2617}$ & $\underline{45}$ & KRAS-Mut.KLVVVGADGV.+2y6.dimethyl-medium & $\underline{26.1}$ \\
\hline & $\underline{510.8488}$ & $\underline{418.1932}$ & $\underline{45}$ & KRAS-Mut.KLVVVGADGV.+2y5.dimethyl-medium & $\underline{26.1}$ \\
\hline & $\underline{510.8488}$ & $\underline{405.3675}$ & $\underline{45}$ & KRAS-Mut.KLVVVGADGV.+2b3.dimethyl-medium & $\underline{26.1}$ \\
\hline & $\underline{510.8488}$ & $\underline{504.4359}$ & $\underline{45}$ & KRAS-Mut.KLVVVGADGV.+2b4.dimethyl-medium & $\underline{26.1}$ \\
\hline & $\underline{510.8488}$ & $\underline{603.5044}$ & $\underline{45}$ & KRAS-Mut.KLVVVGADGV.+2b5.dimethyl-medium & $\underline{26.1}$ \\
\hline & $\underline{510.8488}$ & $\underline{846.5899}$ & $\underline{45}$ & KRAS-Mut.KLVVVGADGV.+2b8.dimethyl-medium & $\underline{26.1}$ \\
\hline & & & & & \\
\hline & $\underline{506.8237}$ & $\underline{517.2617}$ & $\underline{45}$ & KRAS-Mut.KLVVVGADGV.+2y6.dimethyl-light & $\underline{26.1}$ \\
\hline & $\underline{506.8237}$ & $\underline{418.1932}$ & $\underline{45}$ & KRAS-Mut.KLVVVGADGV.+2y5.dimethyl-light & $\underline{26.1}$ \\
\hline & $\underline{506.8237}$ & $\underline{397.3173}$ & $\underline{45}$ & KRAS-Mut.KLVVVGADGV.+2b3.dimethyl-light & $\underline{26.1}$ \\
\hline & $\underline{506.8237}$ & $\underline{496.3857}$ & $\underline{45}$ & KRAS-Mut.KLVVVGADGV.+2b4.dimethyl-light & $\underline{26.1}$ \\
\hline & $\underline{506.8237}$ & $\underline{595.4541}$ & $\underline{45}$ & KRAS-Mut.KLVVVGADGV.+2b5.dimethyl-light & $\underline{26.1}$ \\
\hline & $\underline{506.8237}$ & $\underline{652.4756}$ & $\underline{45}$ & KRAS-Mut.KLVVVGADGV.+2b6.dimethyl-light & $\underline{26.1}$ \\
\hline & $\underline{506.8237}$ & $\underline{838.5397}$ & $\underline{45}$ & KRAS-Mut.KLVVVGADGV.+2b8.dimethyl-light & $\underline{26.1}$ \\
\hline
\end{tabular}

Table S1: MRM transition and optimized parameters for the KRAS ${ }^{\mathrm{WT}}$ (KLVVVGAGGV) and KRAS ${ }^{\mathrm{G} 12 \mathrm{D}}$ (KLVVVGADGV) peptides. 
bioRxiv preprint doi: https://doi.org/10.1101/2020.06.15.149021; this version posted June 16, 2020. The copyright holder for this preprint (which was not certified by peer review) is the author/funder, who has granted bioRxiv a license to display the preprint in perpetuity. It is made available under aCC-BY-NC-ND 4.0 International license.

Rive et al., DD MMM YYYY - preprint copy - BioRxiv

S1-A: KRAS ${ }^{\mathrm{WT}}$ (KLVVVGAGGV)

Peptide MS2 Spectrum

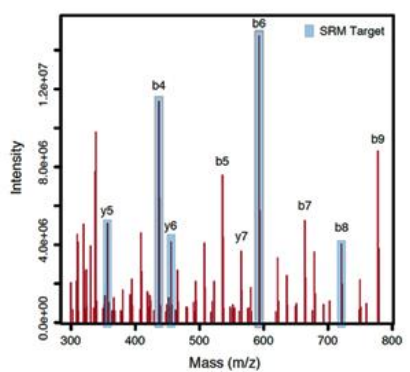

S1-B: KRAS'WT (KLVVVGAGGV)-Light

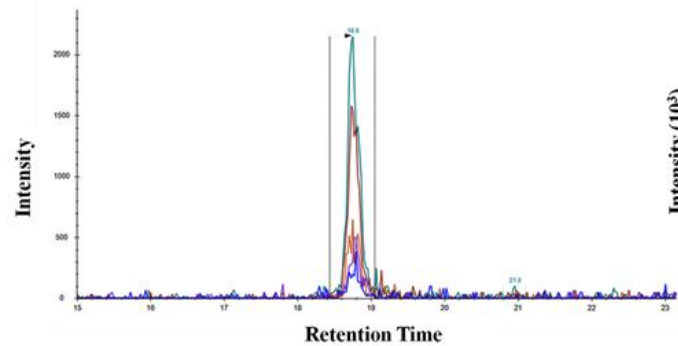

S1-D: KRAS ${ }^{\text {G12D }}$ (KLVVVGADGV)-Light

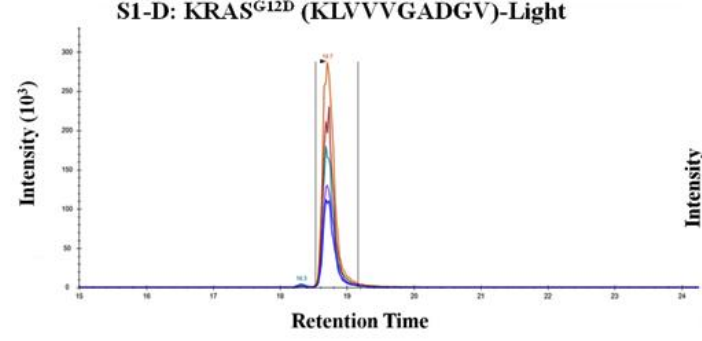

S1-B: KRAS ${ }^{\text {G12D }}$ (KLVVVGADGV)

Peptide MS2 Spectrum

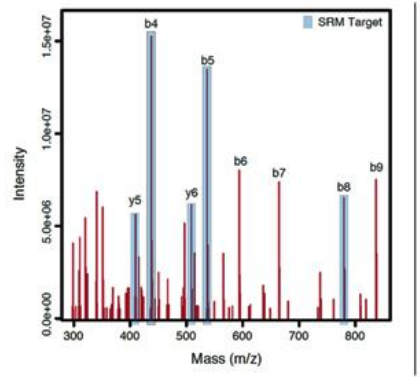

S1-C: KRAS ${ }^{\text {WT }}$ (KLVVVGAGGV)-Heavy

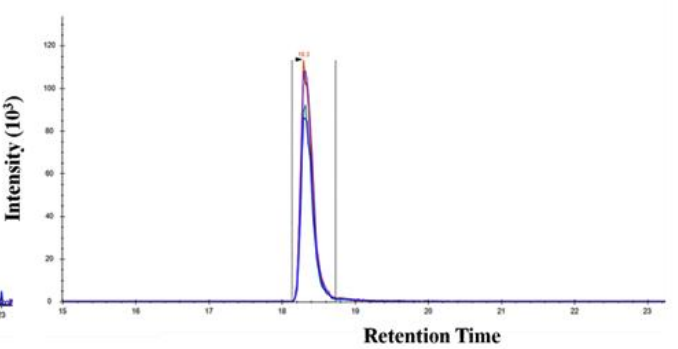

S1-E: $\operatorname{KRAS}^{\text {G12D }}$ (KLVVVGADGV)-Heavy

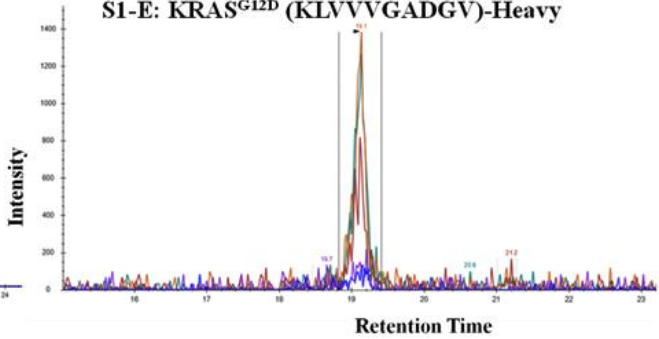

S1-G: PANC-1 peptide elution quantities

\begin{tabular}{lccc}
\hline Peptide & $\begin{array}{c}\text { Normalised Area } \\
\text { (Mean) }\end{array}$ & $\begin{array}{c}\text { Quantity } \\
\text { (fmol) }\end{array}$ & $\begin{array}{c}\text { Quantity } \\
\text { (copies /cell) }\end{array}$ \\
\hline $\begin{array}{l}\text { KRASWT } \\
\text { (KLVVVGAGGV) }\end{array}$ & 30600 & 610 & 14700 \\
\hline $\begin{array}{l}\text { KRAS } \\
\text { (KL12D }\end{array}$ & 1320 & 30 & 720 \\
\hline
\end{tabular}

Figure S1: Mass spectrometry analysis of HLA-A*02:01-restricted KRAS ${ }^{\text {wt }}$ (KLVVVGAGGV) and KRAS ${ }^{\text {G12D }}$ (KLVVVGADGV) aa5-14 peptides eluted from PANC-1 cells. Product-ion peaks for the for KRAS ${ }^{\mathrm{wt}}$ and KRAS ${ }^{\mathrm{G} 12 \mathrm{D}}$ aminoacid 5-14 peptides, respectively (Figure S1-A, -B). Peak areas for the synthetic peptide standard (Figure S1-C, -D), and the corresponding peak areas for peptide eluted from Panc1 cells (Figure S1-E, -F). The area values and quantities of both KRAS ${ }^{\mathrm{WT}}$ and $\mathrm{KRAS}^{\mathrm{G} 12 \mathrm{D}}$-specific HLA*02:01-restricted peptides eluted off PANC-1 cells (Figure S1-G). Although it was less abundant than the $\mathrm{KRAS}^{\mathrm{wt}}$ peptide, the HLA-A*02:01-restricted $\mathrm{KRAS}^{\mathrm{G} 12 \mathrm{D}}$ peptide can be naturally processed and presented by cells which carry the KRAS ${ }^{\mathrm{G} 12 \mathrm{D}}$ mutation and the HLA-A*02:01 allele. 
bioRxiv preprint doi: https://doi.org/10.1101/2020.06.15.149021; this version posted June 16, 2020. The copyright holder for this preprint (which was not certified by peer review) is the author/funder, who has granted bioRxiv a license to display the preprint in perpetuity. It is made available under aCC-BY-NC-ND 4.0 International license.

Rive et al., 15 Jun 2020 - preprint copy version 1 - BioRxiv

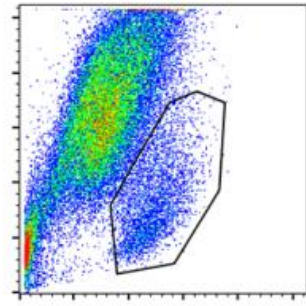

FSC-H

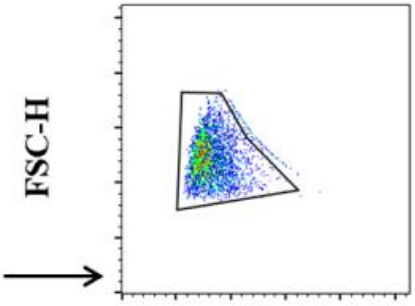

FSC-W

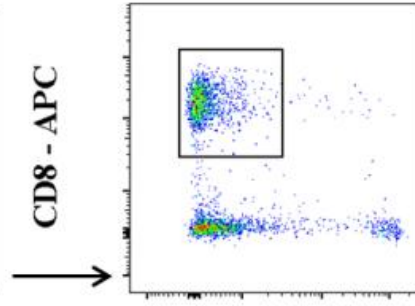

PI Live:Dead

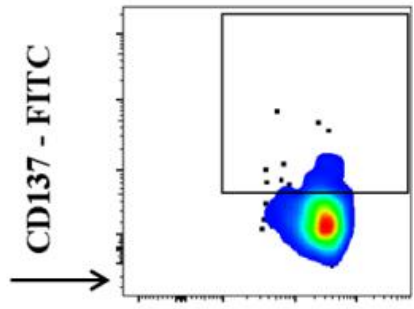

CD8 - APC

Figure S2: CD137 single cell sort of $\mathrm{KRAS}^{\mathrm{G12D} / \mathrm{V} / \mathrm{WT}}$-specific HLA-A*02:01-restricted T cell clones. After debris was eliminated by FSC-A vs. SSC-A gating, cell doublets and clumps were then eliminated by FSC-W vs. FCS-H gating. Live CD8 ${ }^{+}$ $\mathrm{T}$ cells were determined by gating on the PI negative and $\mathrm{CD} 8^{+} \mathrm{T}$ cells. $\mathrm{CD} 137^{+}$expressing $\mathrm{CD} 8^{+} \mathrm{T}$ cells were identified by $\mathrm{CD} 8$ vs. CD137 gating and the $\mathrm{CD} 137^{+} \mathrm{CD}^{+} \mathrm{T}$ cells were single cell sorted into 96-well $\mathrm{U}$ shaped plate and expanded.

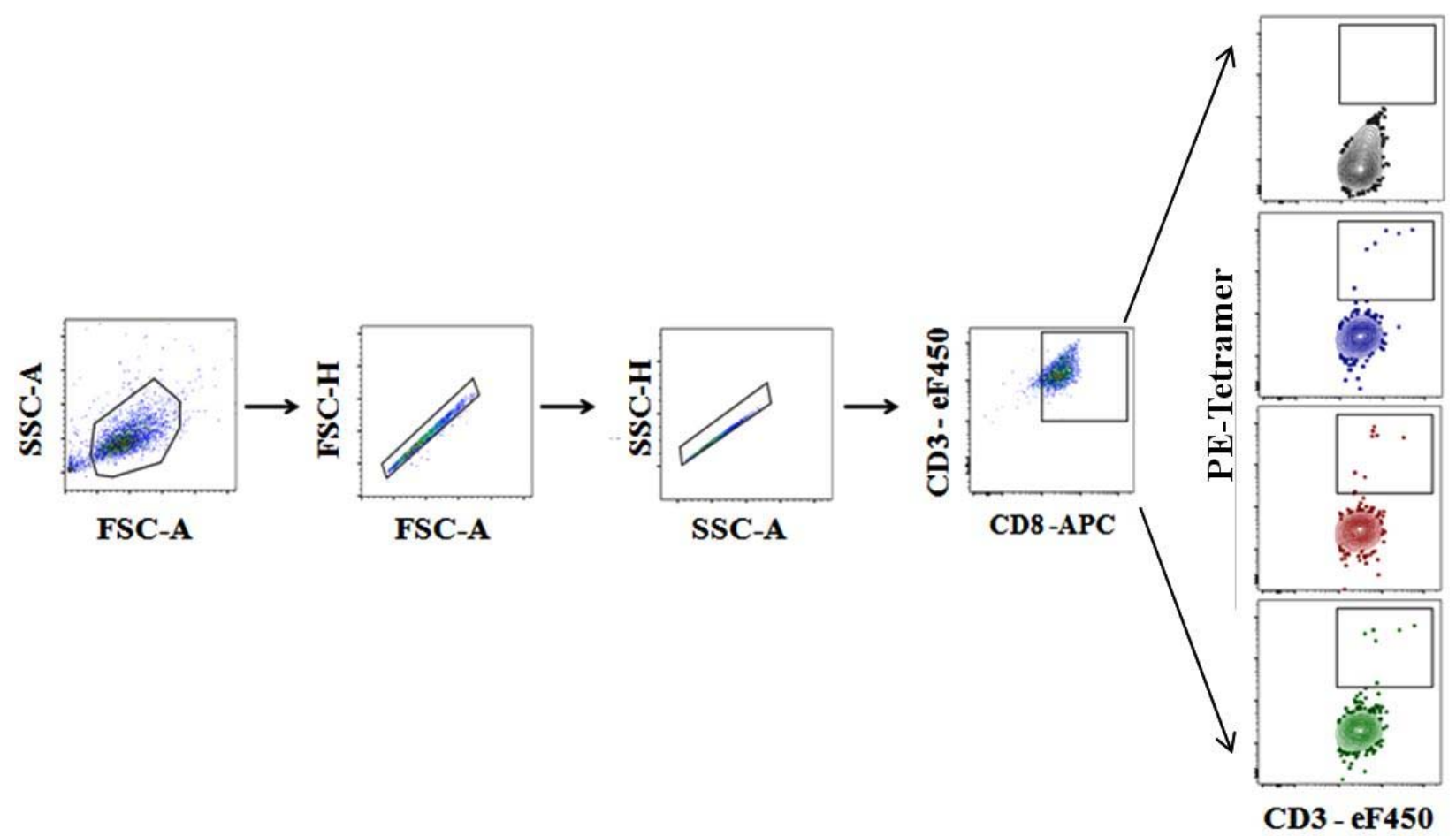

Figure S3: Tetramer staining flow gating protocol. After debris was eliminated by FSC-A vs. SSC-A gating, cell doublets and clumps were then eliminated by FSC-A vs. FSC-H gating followed by SSC-A vs. SSC-H gating. The cells were then gated for CD3 and CD8 expression, followed by CD3 vs. Tetramer gating. 
bioRxiv preprint doi: https://doi.org/10.1101/2020.06.15.149021; this version posted June 16, 2020. The copyright holder for this preprint (which was not certified by peer review) is the author/funder, who has granted bioRxiv a license to display the preprint in perpetuity. It is made available under aCC-BY-NC-ND 4.0 International license.

Rive et al., DD MMM YYYY - preprint copy - BioRxiv

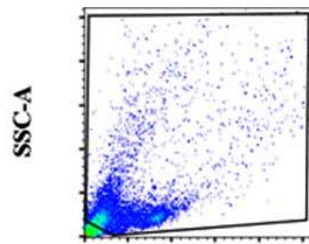

FSC-A

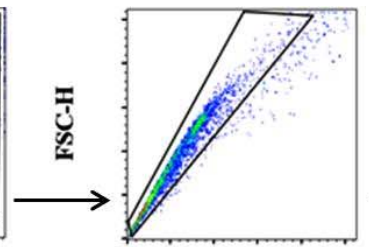

FSC-A

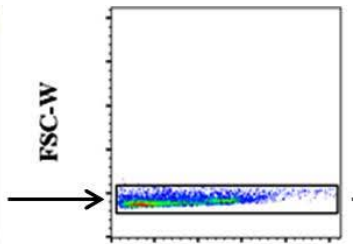

FSC-H

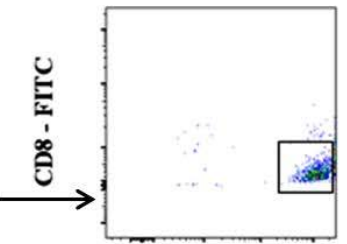

CP eFluor450

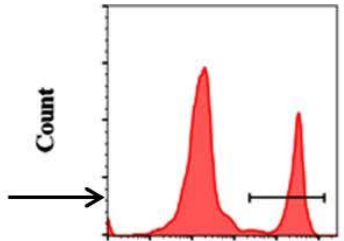

FVS 780 Live:Dead

Figure S4: Cytotoxic assay flow gating protocol. After debris was eliminated by FSC-A vs. SSC-A gating, cell doublets and clumps were then eliminated by FSC-A vs. FCS-H gating followed by FCS-H vs. FCS-W gating. The cell proliferation dye eFluor450 stained, peptide pulsed, K562-A*02:01 positive cells were selected for gating them against CD8-FITC stained cells and then determining the percentage of dead cells by gating on FSV780 stained proportion. The flow collected data was analyzed using Flow Jo v10, for windows and GraphPad Prism software version 8.0.0 for windows (GraphPad Software, California, USA).

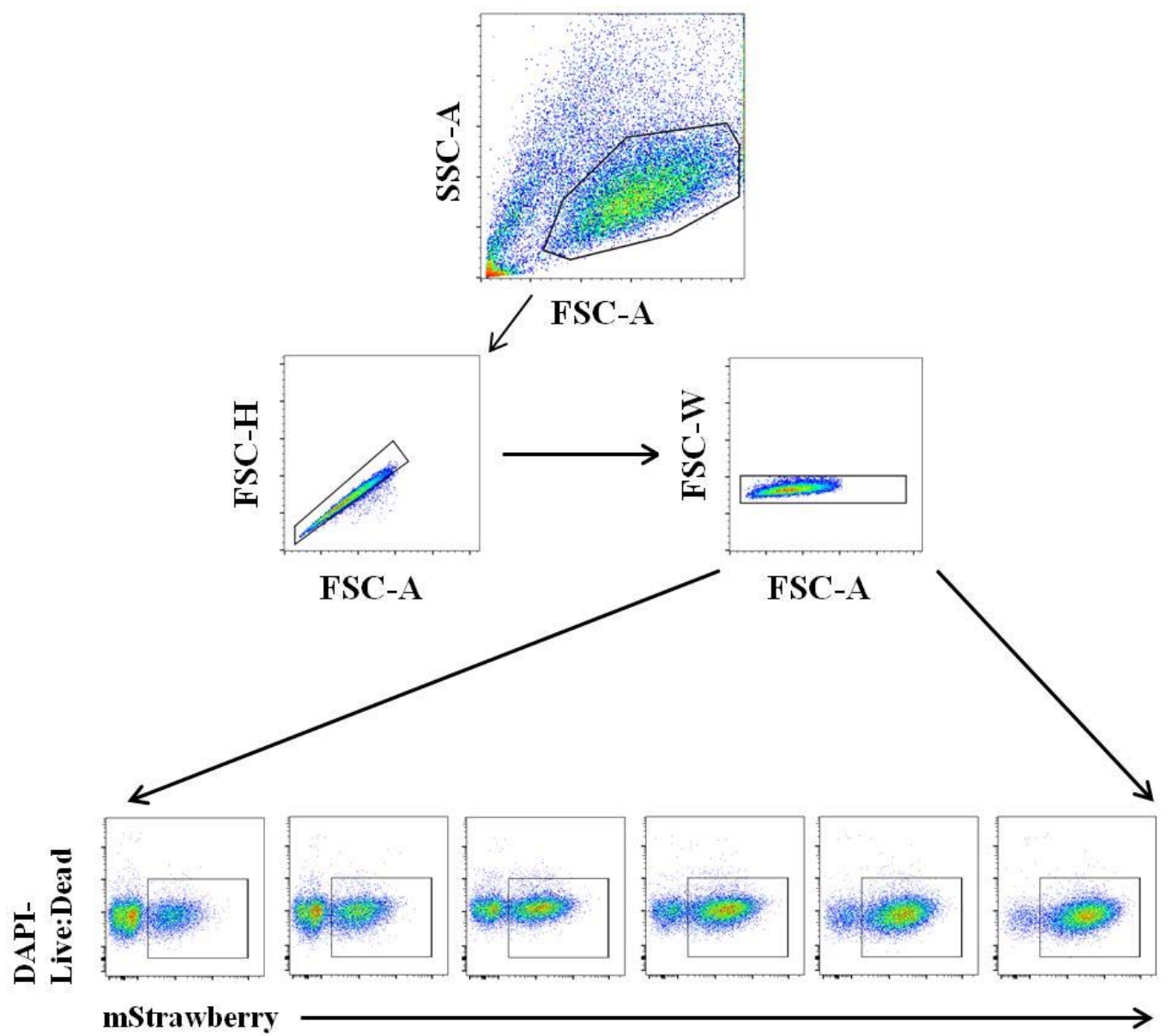

Figure S5: Viral supernatant titration flow gating protocol. After debris was eliminated by FSC-A vs. SSC-A gating, cell doublets and clumps were then eliminated by FSC-A vs. FCS-H gating followed by FCS-A vs. FCS-W gating. The live cells were determined by gating on the DAPI negative cells and on mStrawberry to assess the level of mStrawberry expression within the cells in order to measure transduction efficiency. The flow collected data was analyzed using Flow Jo v10, for windows and GraphPad Prism software version 8.0.0 for windows (GraphPad Software, California, USA). 